\title{
Biofouling and its control in seawater cooled power plant cooling water system - a review
}

\author{
K.K. Satpathy ${ }^{1 *}$, A.K. Mohanty ${ }^{1}$, Gouri Sahu ${ }^{1}$, \\ S. Biswas ${ }^{2}$, M.V.R. Prasad ${ }^{1}$ and M. Slvanayagam ${ }^{2}$ \\ ${ }^{1}$ Environmental and Industrial Safety Section, Indira Gandhi Centre for Atomic Research, \\ Kalpakkam, Tamil Nadu, India, 603102 \\ ${ }^{2}$ Loyola Institute of Frontier Energy, Loyola College, Chennai, India
}

\section{Introduction}

Biofouling may be defined as the attachment and subsequent growth of a community of usually visible plants and animals on manmade structures exposed to seawater environment. Man has long been aware of this problem. In the fourth century B.C., Aristotle is reported to have stated that small "fish" (barnacles) were able to slow down ships. Fouling of ship hulls, navigational buoys, underwater equipment, seawater piping systems, industrial or municipal intakes, beach well structures, oil rigs and allied structures has often been reported. In the past few decades, the list of affected structures has expanded. Now, reports are common regarding the biofouling that affects Ocean Thermal Energy Conversion (OTEC) plants, offshore platforms, moored oceanographic instruments and nuclear and other submarines. The impact of biofouling on sea front structures is staggering. Ships show a $10 \%$ higher fuel consumption caused by increased drag and frictional resistance resulting from hull and propeller fouling. Water lines lose their carrying capacity and speed of flow owing to biofouling growth along pipe systems. The heat exchanger performance declines due to attachment of biofoulants. Many marine organisms themselves face the constant problem of being colonized and overgrown by fouling organisms. Immobile plants and animals are generally exposed to biofouling and consequent loss of species and community assemblages. Biofouling also promotes corrosion of materials. The money and material needed for fouling protection measures are indeed exorbitant. It is estimated that the marine industry incurs an expenditure of 10 billion sterling pounds a year to combat the situations arising from biofouling worldwide (Satpathy, 1990). A lot of research effort has been devoted to understand the fundamental ecology and biology of fouling environments, organisms and communities in diverse settings.

The huge requirement of cooling water as well as accrescent demand on the freshwater has led to the natural choice for locating power plants in the coastal sites where water is available in copious amount at relatively cheap rate. For example, a $500 \mathrm{MW}$ (e) nuclear power plant uses about $30 \mathrm{~m}^{3} \mathrm{sec}^{-1}$ of cooling water for extracting heat from the condenser 
and other auxiliary heat exchanger systems for efficient operation of the plant. However, use of seawater, brings associated problems such as colonization of biota which stands in the way of smooth operation of the plant. Unfortunately, every cooling system with its concrete walls forms a suitable substrate for marine growth. Some of the conditions which favour the development of a fouling community in power plants are (a) continuous flow of seawater rich in oxygen \& food, (b) reduction in silt deposition, (c) lack of competition from other communities and (d) reduction in the density of predators. Broadly speaking the effects of marine growth on the power plant are (a) losses in plant efficiency, (b) mechanical damage and (c) problem for the integrity of the cooling circuits needed for safety of nuclear plants (Nair, 1987). Hence biofouling control aims to achieve efficient operation of the power station at all times. It is therefore necessary for power plant designers to make a rational choice regarding the most suitable control method to combat biofouling problem in a practical, yet economically feasible \& environmentally acceptable manner.

\subsection{Economic impacts of biofouling}

Economics involved in the biofouling problem of power plant as quoted by various authors are cited here to emphasize the importance of biofouling control.

A $5 \mathrm{~mm} \mathrm{Hg}$ condenser back pressure improvement can equal to $0.5 \%$ improvement in the turbine heat rate which approximately equal to 3 additional megawatts of generating capacity (Drake, 1977). Similar increase in condenser back pressure due to fouling in a $250 \mathrm{MW}$ (e) plant can cost the utility about $\$ 2.5$ lakhs annually (Chow et al., 1987). One report estimates that fouling by Asiatic clam alone costs the nation over a billion \$ annually (Strauss, 1989). Costs for one day unplanned outage can run into $0.3 \%$ of their earning per year, taking 300 days operation. Hence eliminating one unplanned outage can more than pay for measures taken to maintain cooling water tube cleanliness. Waterside resistance accounts for $72 \%$ of the total resistance to heat transfer of the tube. Of this, the film which forms in a condenser tube accounts for a significant $39 \%$ and the rest $33 \%$ is due to scaling (Drake, 1977).

The experience of Marchwood (Southampton) showed that between 1957 and 1964, 4000 condenser tubes failed due to mussel fouling leading to leakage. Apart from the loss of generation, these leaks contaminated the feed water system and accelerated the boiler water side corrosion, resulting in boiler tube failures (Coughlan and Whitehouse, 1977). The inlet culverts had to be drained for manual cleaning at least once in a year. Average quantity of mussel removed was 40 tons but could be as high as 130 tons. Similar stations at Pools (Dorset) had a maximum 300 tons (Coughlan and Whitehouse, 1977). About 300 tons of mussel shells were removed each time by shock chlorination from MAPS intake tunnel on two occasions. Cost (at 1975 prices) of dropping a 500 MW (e) oil-fired station at Fawley (Southampton) was 15000 pounds per day due to fouling, excluding repairs. The cost of chlorine for this unit for the whole year of 1975 was 7500 pound. The consequence of inadequate chlorination at Inland station eventually led to the unit being taken off load for manual cleaning of condenser (Coughlan and Whitehouse, 1977). It has been observed by the CEGB investigating team on biofouling control practices that stress corrosion cracking of admirality brass condenser tubes was attributed to ammonia produced by bacteria (Rippon, 1979).

The cleaning out of biofouling from the cooling water intake tunnels and culverts is generally very expensive; for instance 4000 man hours were used to clean the culverts and to remove $360 \mathrm{~m}^{3}$ of mussels at Dunkerque in 1971 (Whitehouse et al., 1985). Within a very short time at Carmarthen Bay Power Station, which was commissioned in July 1953, seed 
mussels and various species of marine life were noticed around the main intake to the cooling water system. By april 1954 the fouling was so severe that plant was shutdown daily, increasing to 3 times per shift by mid July when operation of the station became almost impossible (James, 1967). At the Tanagwa Power Station in Japan the concrete under ground conduit was covered with layers of attached organisms sometimes measuring to about $70 \mathrm{~cm}$ thickness. A large quantity of jelly fish (150 tons/day) was also removed from this station in one instance (Kawabe et al., 1986).

An analysis of all tube failures at Kansai Electric Power Corporation (Japan) in 1982 and 1983 showed that $94 \%$ of all tube failures were related to macrofouling lodged in the tubes (Kawabe et al., 1986). Microfouling seems to be a major obstacle to the successful development of the ocean thermal conversion concept into a useful solution to the world's energy supply (Corpe, 1984 and Darby, 1984). It has been reported that up to $3.8 \%$ loss in unit availability in large power plants could be attributed to poor condenser tube and auxiliary system reliability (Syrett and Coit, 1983). A 250 micron thick layer of slime may result in up to a $50 \%$ reduction in heat transfer by heat exchangers (Goodman, 1987).

\subsection{Bio-growth in different sections of a cooling water system}

A typical cooling water system of a power plant involves a pre-condenser system and the heat exchangers which includes main condenser and process water heat exchangers. The pre-condenser system involves the intake structures and the cooling water system from intake to the pump house. The intake system is either an open canal or pipeline or a tunnel. It has been observed that macrofouling generally takes place in the pre-condenser system whereas, microfouling is observed in the condenser and process water heat exchangers. This could be due to difference in the various features like flow, temperature, space etc at different parts of the cooling water system. In spite of various physical measures such as trash rack, intake screen, travelling water screen, to control biofouling, the tiny larval forms of various organisms enter the system, settle and colonize inside it and finally affect the smooth operation of the cooling water system. These organisms clog cooling water flow endangering the safety-related systems at some power plants. During the construction, when the tunnel is ready and the biocide treatment plant is yet to be operational, the intake structure gets severely fouled by macrofoulers. Despite efforts to provide an effective design of heat exchanger and careful attention to the maintenance of the design operating conditions, it is likely that fouling on the water side of the heat exchangers will occur unless suitable precautions are taken. The common practice of taking water from natural sources such as rivers and lakes for cooling purposes means that it contains micro- and macroorganisms, which will colonize the heat transfer surfaces, to the detriment of cooling efficiency. The problem will be aggravated by the fact that the temperature of the waterside surface in the heat exchanger is usually close to the optimum temperature for maximum microbial growth. In addition, water from natural sources contains nutrients from the breakdown of naturally occurring organic material. Unless this bioactivity is controlled the efficiency of the heat exchanger will be seriously reduced.

\subsection{Biofouling and safety consequences of nuclear power plants}

Many nuclear power plants have experienced fouling in their cooling water systems (Satpathy, 1996). These fouling incidents have caused flow degradation and blockage in a 
variety of heat exchangers and coolers served directly by raw water. In addition, loose shells from dead organisms are carried by the flow until they are trapped or impinged in small piping, heat exchangers, or valves. Often the results of fouling that have accumulated behind inlet valves and in heat exchanger water boxes degrade or compromise the safety function of safety-related components. Events of this nature have occurred at several nuclear plants, which prompted the Nuclear Regulatory Commission of USA to issue warning requiring plants to determine the extent of biofouling and to outline their strategy for controlling it (Henager et al., 1985). A few typical incidents reported in the literature are outlined here. Brunswick power plant I and II reported blockages of their Residual Heat Removal (RHR) heat exchangers in 1981 (Imbro and Gianelli, 1982) by American oyster (Crassostrea virginica) shells. This produced high differential pressures across the divider plate and caused the plate to buckle. The result was a total loss of the RHR system. The plant was forced to provide alternate cooling. American oysters had accumulated in the inlet piping to the RHR heat exchangers, because the chlorination had been suspended for an extended period. RHR heat exchangers at Unit II were also fouled and severely plugged. The Salem II (S.M. Stoller Corp. 1983) and the Arkansas Nuclear I power plant have reported flow blockages to containment fan cooling units (plugging a backpressure control valve, which restricted flow in the containment fan cooling units) and fouling of containment cooling units respectively (Nuclear Regulatory Commission, 1984, Haried, 1982). Blue mussel shells deposits in the water jacket cooler of a diesel generator at Salem I $\&$ Millstone II plant caused the generator to overheat and subsequently trip off (S. M. Stoller Corp. 1977). An industrial processing plant experienced severe Asiatic clam (Corbicula fluminea) fouling in its fire protection lines because of frequent flow testing at reduced flow rates. When full flow testing was initiated after several years of operation, the sudden flow surge caused severe blockage in the main and branch piping (Neitzel et al., 1984). Fouling in fire protection systems by Asiatic clam has also been reported at Browns Ferry (Tennessee Valley Authority, 1981) and McGuire power plant (Duke Power Co., 1981). The main condenser at Browns Ferry 1 was severely fouled with Asiatic clams only a few months after the plant began operation in 1974 and the problem increased subsequently (Rains et al., 1984). At Pilgrim I power plant, blue mussels blocked cooling water flow and caused an increase in differential pressure across the divider plates, forcing the plates out of position leading to loss of Reactor Building Closed Cooling Water (RBCCW) heat exchanger capacity (Imbro, 1982). At Trojan power plant, Asiatic clams plugged one of the heat exchangers that cool the lubricating oil to the main turbine bearings (Portland General Electric Co., 1981). Temporary stoppage of normal preventive maintenance during an extended plant shutdown at San Onofre I power plant allowed barnacles (Pollicipes plymerus) to incapacitate a component cooling water heat exchanger (Henager et al., 1985). In the same plant a butterfly valve malfunctioned on the seawater discharge side of the cooling water heat exchanger because massive growth of barnacles had reduced the effective diameter of the pipe and impeded valve movement (Henager et al., 1985). In September 1984, St. Lucie power plant reported plugging of its intake screens by Jellyfish (Henager et al., 1985). In August 1983, Calvert Cliffs I power plant tripped manually to avoid an automatic turbine/ reactor trip due to low condenser vacuum, which was the result of shutting down two of six circulating cooling water pumps because their inlet screens had become plugged with fish (Nuclear Regulatory Commission, 1984). 


\subsubsection{Events that could exacerbate fouling}

Some of the non-fouling events could cause a normal bifouling situation to become serious. Generally they are three types; 1 ) environmental events that affect fouling populations within the plant and in the vicinity of the plant, 2) plant operating events or procedures that may dislodge or kill fouling organisms, and 3) biofouling surveillance and control procedures that may exacerbate fouling.

\section{a. Environmental Events}

The following environmental events could occur at nuclear power plants site and affect safe plant operation. Dynamic shocks due to seismic activity, explosions (intentional and accidental), or similar events could loosen fouling organism from their substrate and these can subsequently clog heat exchangers downstream. Heavy rain storms and flooding could wash bivalves from their substrate and carry them into the intake pumps. It can also create a thermal shock which could kill fouling organisms and fish leading to blockage of cooling water systems. Heavy rains also have the potential of creating an osmotic shock due to a rapid decrease in the salinity of the cooling water source resulting in massive killing of fouling organisms. Toxic chemical spills (pesticides, herbicides, industrial chemicals, oil, etc.) due to tanker spills and leakage of pipe line upstream of the plant could kill fouling organisms in the cooling water source and within the plant.

\section{b. In-plants}

Some transients and operating procedures that occur during the operation of nuclear power plants can affect biofouling. Although, most of these procedures are necessary, however, several improvements could be made to eliminate or reduce biofouling events associated with these procedures. The following in-plant events have occurred at nuclear power plants leading to dislodge or movement of fouling organism. Sudden changes in flow velocity (increases in velocity) have washed accumulations of bivalves into heat exchangers. Changes in flow direction may also cause bivalves to move into areas with higher velocity from where they can be swept downstream. Sudden gush of cooling water (Water hammer) has been implicated as a cause of heat exchanger clogging at Arkansas Nuclear I plant (due to dislodging of Asiatic clams) and at the Brunswick plant (American oysters) allowing them to be swept into their Residual Heat Removal heat exchangers (Harried, 1982). Thermal shock from either a rapid cooling or heating of the raw water can kill bivalves. At pilgrim power plant, the inadvertent routing of heated water into the service-water intake structure from a condenser backwashing operation caused a massive kill of blue mussels in the intake structure and in the service-water headers (Satpathy et al., 2003). The plant was forced to reduce power to $30 \%$ while blue mussels continued to break loose and plug the Reactor Building Closed Cooling Water (RBCCW) heat exchangers. This continued for approximately 3 months. Allowing bivalve shells to accumulate in the intake structure and in areas of the raw-water system encourages clogging and lead to reduced suction head and vortexing problems in the circulating water and service-water. It was reported that accumulations of Asiatic clam shells and silt up to $90 \mathrm{~cm}(3 \mathrm{ft})$ deep are not uncommon in the intake structure (Satpathy et al., 2003). Blue mussels have also been described as forming 1.2-m-thick (4-ft-thick) mats on the walls of intake structures (Henager et al., 1985). Starting up of inactive systems has led to clogging when precautions were not taken to prevent bivalves from entering and growing in those systems. The initial flow surge through the system can carry loose bivalves and shells into constricted areas downstream. Chronic fouling has been reported in raw-water cooling loops that are used infrequently (Henager et al., 1985). 
Chemical such as diesel oil, lubricating oil, and other toxic chemicals used at nuclear plants could spill in the intake structure and kill fouling organisms. Pump cavitation from plugged suction lines to the pumps would result in increased wear and decreased performance of service-water booster pumps and the main pumps in the fire protection system. The vibration of lines associated with cavitating pumps may also dislodge bivalves and cause fouling downstream. Flushing fouling organisms into drains and sumps could cause plugging and subsequent flooding of equipment rooms. This could damage electrical equipment such as pump motors, electronic instrumentation, and motor-controller valves. Leaking valves have allowed the continuous flow of water to carry food and oxygen to bivalves. Several utilities indicate this as a major cause of fouling in plants (Henager et al., 1985). The same effect may occur in lines where valves are inadvertently left in the semiopened position. Near stagnant conditions in water systems provide ideal conditions for bivalve growth. This is especially true for Asiatic clams. Most plants typically operate with nearly $80 \%$ of the cooling loops in this condition (Neitzel et al., 1984) in order to maintain redundant cooling loops in standby condition. Damaged or missing intake screens and strainers have allowed adult organisms to be sucked into the cooling water system. Also, severe plugging from weeds, grass, and ice have caused the automatic strainer wash systems to malfunction at Salem 1 plant (S.M.Stoller Corp. 1978) and at Indian Point 3 plant (S.M. Stoller Corp. 1983).

\section{c. Surveillance and control procedures}

Biofouling control techniques can be divided into two major categories, detection / surveillance and control / prevention programs. Surveillance refers to detecting the biofouling and the subsequent flow degradation. The goal of control techniques, however, is to limit biofouling to a safe and acceptable level. Surveillance and control procedures could cause organisms to flourish or to become dislodged (Daling and Johnson, 1985). Thermal backwashing, although an effective method of killing bivalves, can result in enhanced clogging of heat exchangers when measures are not taken to remove the bivalves that are killed. It is also important to account for the time lag between the thermal treatment and the detachment of the bivalves. This is especially true for blue mussel and American oyster fouling. Thermal backwashing should be scheduled to prevent bivalves from growing large enough to block condenser tubes. Similarly, when shock chlorination is used to kill the established community and subsequently care is not taken to remove them, they accumulate and clog downstream (Fig. 1).

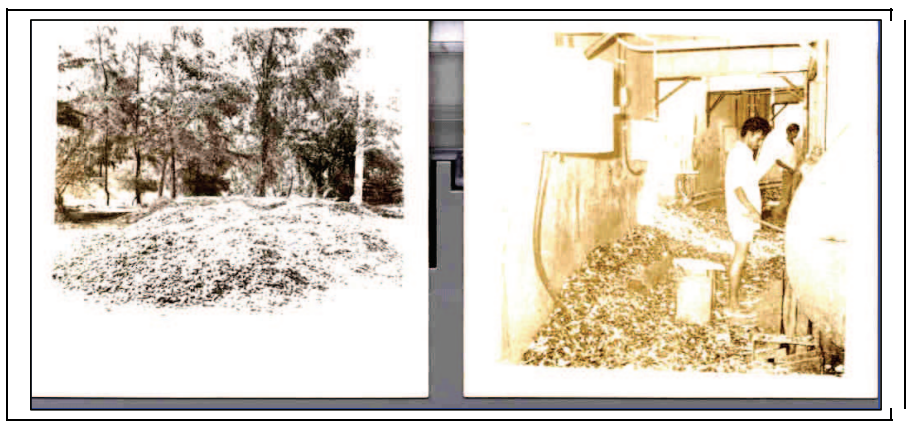

Fig. 1. Removed fouling organisms from the tunnel of a seawater cooled nuclear power plant (Madras Atomic Power Station) by shock chlorination 
Increased flow rates during testing can wash bivalves into heat exchangers. This is especially true of Asiatic clam fouling because adults lose the ability to attach to substrates and will be flushed into downstream heat exchangers at increased flow rates. The initial flow testing or flushing of a stagnant, infested line has led to an unexpectedly large number of bivalves which occurred at Browns Ferry 1 power plant, when the condenser circulating water system was started up after construction was completed. An intermittent chlorination system that malfunctioned and released a massive dose of chlorine to the intake killed large numbers of bivalves. These bivalves later detached and clogged heat exchangers. The intermittent chlorine application would not control bivalves in the system, but a large chlorine spill may be concentrated enough and last long enough to kill bivalves.

The following enhanced growth events have occurred at nuclear power plants due to procedures or strategies. Infrequent or inadequate chlorination caused by faulty or wrongly calibrated chlorinating metering systems or by intentional, intermittent applications of chlorine have allowed bivalves to survive in raw-water systems. Personnel from several plants remarked that bivalve fouling became worse when the chlorination system was out of service for an extended period. Intermittent chlorination to control slime and other microfouling has been ineffective in controlling bivalves because, they are able to close their shells tightly during periods of chlorination. Failure to chlorinate normally stagnant cooling loops, which already have a high potential for fouling, can substantially increase the fouling potential of the system. Frequent flow testing, particularly if done at low flow velocity, may improve the growth potential of the system by providing a more frequent supply of food and oxygen to bivalves. This effect is intensified if flow testing is not concomitant with chlorination. The intermittent, "non-design" use of the fire protection system to water lawns and wash equipment has also provided enhanced conditions for Asiatic clam growth.

\subsection{Biofouling at Madras Atomic Power Station}

The best approach to understand biofouling problem in a seawater cooled power plant is by taking a typical example which has been studied well. The Madras Atomic Power Station

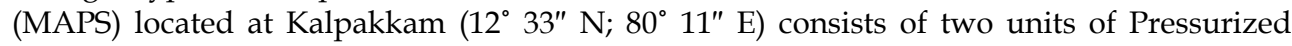
Heavy Water Reactor (PHWR), each of $235 \mathrm{MW}$ (e) capacity. Seawater is used at the rate of $35 \mathrm{~m}^{3} \mathrm{sec}^{-1}$ as the coolant for the condenser and process cooling water systems. A sub-seabed tunnel located $53 \mathrm{~m}$ below the bottom terrain draws seawater (Fig. 2). The tunnel is $468 \mathrm{~m}$ long and $3.8 \mathrm{~m}$ in diameter. It is connected at the landward end to the pump house through a vertical shaft of $53 \mathrm{~m}$ deep and $6 \mathrm{~m}$ diameter called forebay. Similarly, the seaward end of the tunnel is connected to a vertical shaft of $48 \mathrm{~m}$ and $4.25 \mathrm{~m}$ diameter called intake. Seawater enters the intake through 16 windows located radially at the intake structure, $1 \mathrm{~m}$ below the lowest low water spring tide. The tunnel, intake and forebay shafts support a heavy growth of benthic organisms such as mussels, barnacles, oysters, ascidians etc. The high density of these fouling organisms inside the tunnel/cooling systems could be attributed to continuous supply of oxygen \& food and removal of excretory products by the passing seawater providing a conducive environment for their settlement and growth. In addition, absence of any potential predator inside the cooling system supports a luxuriant growth of these communities. The physical shape of the tunnel is such that it is an isolated system open at both ends; seawater samples can be collected at intake as the control location, whereas, samples collected at forebay after flowing past the fouling communities can be investigated for change in its physicochemical properties. 
Biofouling in the cooling system of seawater-cooled power plants is a universal problem (Brankevich et al., 1988; Chadwick et al., 1950; Collins, 1964; Holems, 1967; James, 1967; Relini, 1980; Satpathy, 1990). It is of considerable interest as it imposes penalty on power production, impairs the integrity of cooling system components and in some cases even precipitates safety problems associated with cooling system of nuclear power plants (Henager et al., 1985; Rains et al., 1984), which has been already discussed. Different aspects of biofouling in the cooling conduits of coastal power plant from tropical as well as temperate regions have been studied by several researchers (Brankevich et al., 1988; Chadwick et al., 1950; Collins, 1964; Holems, 1967; James, 1967; Relini, 1984; Satpathy, 1990; Sashikumar, 1991). The problem of biofouling in a tropical seawater cooled power plant can be understood by explaining a typical case study. Studies carried out in this regard from Indian coast have not been exhaustive however, from Kalpakkam coast, south east coast of India, it has been immense due to its importance to the existing MAPS. Biofouling has been a serious problem in the cooling water system of MAPS. It had affected adversely the cooling system and performance of the plant (Sashikumar, 1991; Rajagopal, et al., 1991; Satpathy et al., 1994). Investigation on the fouling problems of MAPS cooling system indicated extensive settlement of macro-fouling organisms inside the tunnel, which was calculated to be around 580 tonnes (Nair, 1985) that caused severe pressure drops in the cooling circuits.

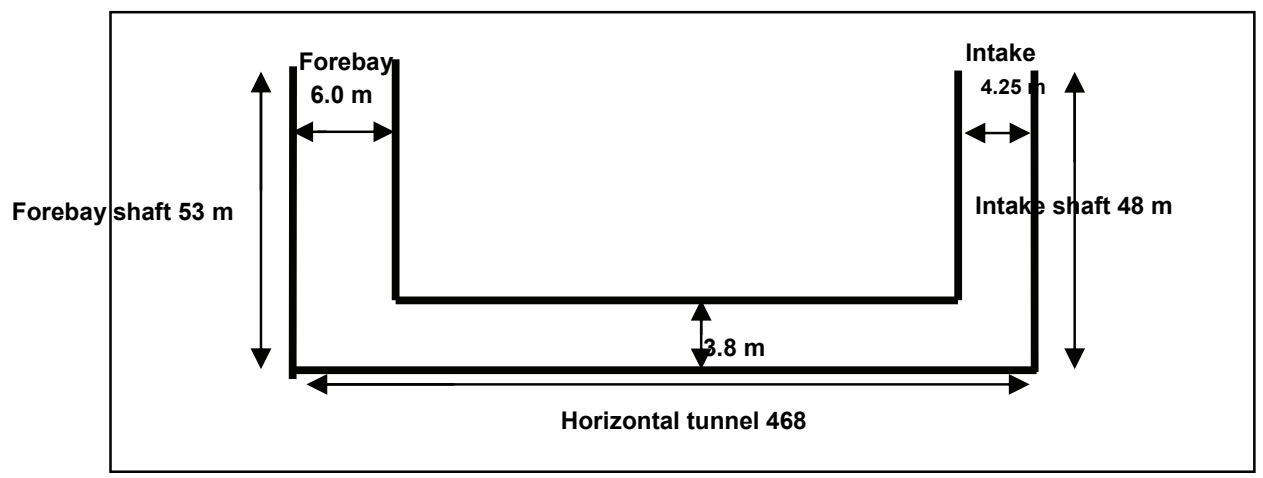

Fig. 2. Schematic diagram of the cooling water structure of MAPS

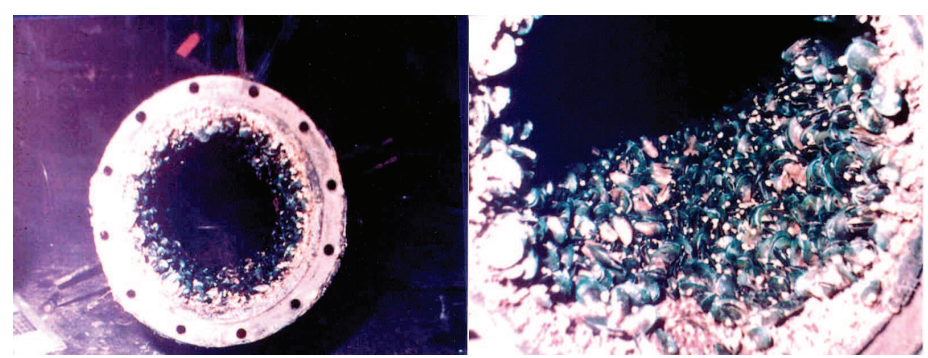

Fig. 3. A view of bio-growth inside seawater pipe lines from MAPS

The intake submarine tunnel was observed to have a maximum of $25 \mathrm{~cm}$ thick layer of fouling organism with an average of $18 \mathrm{~cm}$ (Satpathy et al., 1994). A typical blockage of a 
cooling water pipe is shown in Fig. 3. In addition stupendous growth of fouling organisms on the intake screen (Fig. 4a) of MAPS impedes its smooth operation (Satpathy, 1996). The condenser tubes of MAPS were severely affected by the clogging of dead green mussel (Fig. 4b) (Satpathy, 1996). Similarly, jelly fish ingress and clogging of intake and traveling water screen forcing the plant authorities to shut down the reactor (Masilamani et al., 2000), has been another problem. Albeit, it is a seasonal issue, it also plays havoc with the operation of the cooling water system and ultimately power plant operation.

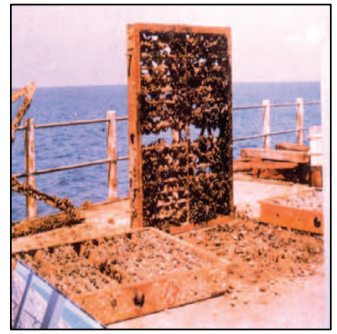

(a)

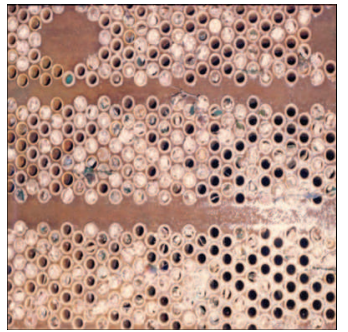

(b)

Fig. 4. Blockage of intake screen by fouling organisms (a) and blockage of condenser tubes by green mussels \& barnacles (b)

\section{Description of the locality}

Kalpakkam coast $\left(12^{\circ} 33^{\prime} \mathrm{N}\right.$ Lat. and $80^{\circ} 11^{\prime}$ E Long.) is situated about $80 \mathrm{~km}$ south of Chennai (Fig. 5). At present a nuclear power plant (MAPS) and a desalination plant are located near the coast. MAPS uses seawater at a rate of $35 \mathrm{~m}^{3} \mathrm{sec}^{-1}$ for condenser cooling purpose. The seawater is drawn through an intake structure located inside the sea at about $500 \mathrm{~m}$ away from the shore. After extracting heat, the heated seawater is released into the sea. Two backwaters namely the Edaiyur and the Sadras backwater system are important features of this coast. These backwaters are connected to the Buckingham canal, which runs parallel to the coast. Based on the pattern of rainfall and associated changes in hydrographic characteristics at Kalpakkam coast, the whole year has been divided into three seasons viz: 1) Summer (February-June), 2) South West (SW) monsoon (July-September) and 3) North East (NE) monsoon (October-January) (Nair and Ganapathy, 1983). Seasonal monsoon reversal of wind is a unique feature of Indian Ocean that results in consequent change in the circulation pattern (La Fond, 1957; Wyrtki, 1973), which is felt at this location too. The wind reversal occurs during the transition period between the SW monsoon and NE monsoon. In general, the SW to NE monsoon transition occurs during September/ October and the NE to SW transition occurs during February/ March. The pole-ward current during SW monsoon changes to equator-ward during the SW to NE monsoon transition, whereas, a reverse current pattern is observed during the transition period between NE to SW monsoon (Varkey et al., 1996; Vinaychandran et al., 1999; Haugen et al., 2003). Subsequent to the change in the current pattern, the alterations of coastal water quality have been reported (Somayajulu et al., 1987; Ramaraju et al., 1992; Babu, 1992; Saravanane, 2000). The phenomenon of upwelling has also been reported to occur during the pre-NE monsoon period in the southeast coast of India in low temperature and high saline water mass (De Souza et al., 1981; La Fond, 1957; Ramaraju et al., 1992, Suryanarayan and Rao, 1992). During 
the period of NE monsoon and seldom during SW monsoon monsoon, the two backwaters get opened to the coast discharging considerable amount of freshwater to the coastal milieu for a period of 2 to 3 months. This part of the peninsular India receives bulk of its rainfall ( $70 \%$ ) from NE monsoon. The average rainfall at Kalpakkam is about $1200 \mathrm{~mm}$. However, with the stoppage of monsoon, a sand bar is formed between the backwaters and sea due to the littoral drift, which is a prominent phenomenon in the east coast of India, resulting in a situation wherein the inflow of low saline water from the backwaters to sea is stopped. This location had been badly affected by 2004 mega Tsunami, which devastated the entire east coast of India and had maximum impact at this part of the coast.

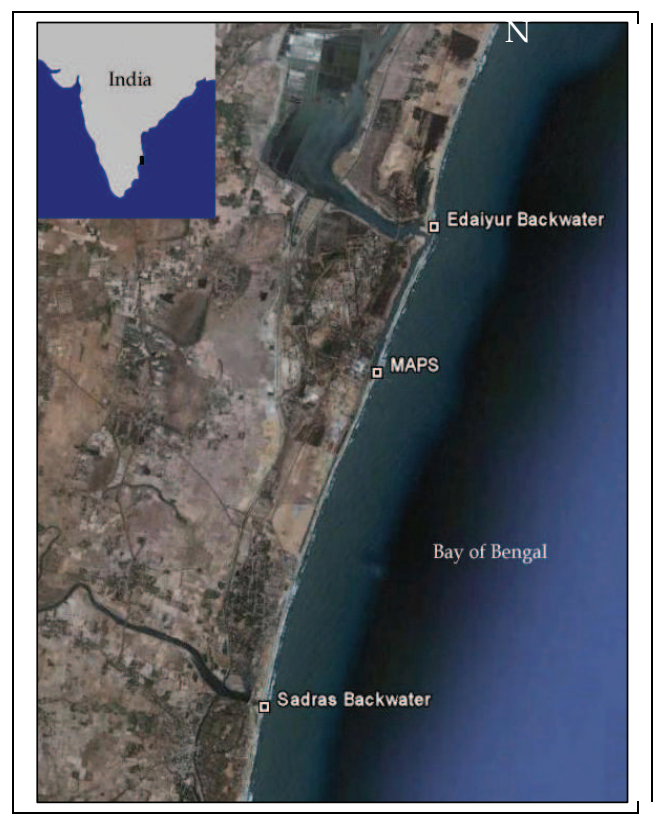

Fig. 5. A map of the study area, Kalpakkam coast, Bay of Bengal

The mean tidal range varied from $0.3-1.5 \mathrm{~m}$. The coastal currents at Kalpakkam has seasonal character and during SW monsoon the current is northerly (February to October) with a magnitude of $0.2-1.8 \mathrm{~km} / \mathrm{h}$ and during NE monsoon the current is southerly (October to February) with a magnitude of $0.1-1.3 \mathrm{~km} / \mathrm{h}$. The wind speed varied from $10-$ $40 \mathrm{~km} / \mathrm{h}$. These monsoonal winds cause a) southerly $\left(\sim 0.5\right.$ million $\left.\mathrm{m}^{3} / \mathrm{y}\right)$ \& northerly $(\sim 1$ million $\mathrm{m}^{3} / \mathrm{y}$ ) littoral drift (Satpathy et al., 1999). The seawater temperature has two maxima (Apr/May \& Aug/Sept) and two minima (Dec/Jan \& June/July) (Satpathy and Nair, 1990; Satpathy et al., 1999; Satpathy et al., 1997).

\section{Hydrobiological features of coastal waters}

\subsection{Methodology}

Seawater samples were collected weekly near the MAPS cooling water intake for estimation of water quality parameters such as $\mathrm{pH}$, salinity, dissolved oxygen (DO), turbidity, 
chlorophyll- $a$ and nutrients such as, nitrite, nitrate, ammonia, total nitrogen, silicate, phosphate and total phosphorous. Water temperature was measured at the site using a mercury thermometer of $\pm 0.1^{\circ} \mathrm{C}$ accuracy. Salinity was measured using Knudsen's method (Grasshoff et al., 1983). Estimation of DO was carried out following the Winkler's method (Parsons et al., 1982). pH was measured using a pH probe (Cyberscan PCD 5500) with accuracy of \pm 0.01 . Turbidity was measured using Turbidity meter (Cyberscan IR TB100) with accuracy of \pm 0.01 NTU. Chlorophyll- $a$ and nutrients were analyzed following the standard methods of Parsons et al. (1982) using a double beam UV visible spectrophotometer (Chemito).

\subsection{Results}

Hydrographical parameters at this coast bear pronounced seasonal variations (Satpathy et al., 2008, 2010). Temperature varies from 26.0 (August) to $31.8{ }^{\circ} \mathrm{C}$ (May) indicating that the annual gradient remained $\sim 5.8{ }^{\circ} \mathrm{C}$. Seawater temperature is characterized by two maxima, one during April/ May and another during September/ October coinciding with the trend in atmospheric temperature. $\mathrm{pH}$ values ranged between 8.00 and 8.30 with maximum value during NE monsoon period. Salinity ranged from 24.91 (November) - 35.90 psu (May), which showed a unimodal oscillation. Dissolved oxygen (DO) values fluctuated between 4.2 and $6.1 \mathrm{mg} \mathrm{l}^{-1}$. Values of turbidity varied between 9.21 and 21.42 NTU. Chlorophyll- $a$ concentration varies between 1.42 and $7.51 \mathrm{mg} \mathrm{m}^{-3}$ during the month of November and August respectively.

The maximum value of $\mathrm{pH}$ observed, coincides with $\mathrm{NE}$ monsoon period during which not only the precipitation, but also the discharges from the nearby backwaters affect the magnitude of $\mathrm{pH}$ as well as salinity significantly. As expected, the lowest salinity value coincides with the local maximum precipitation period (NE monsoon period) and also with the maximum influx of fresh water from the two nearby backwaters. The highest salinity value coincides with the peak summer. DO shows an irregular pattern of distribution except for the fact that during NE monsoon period, relatively high values are observed as expected due to input of oxygen rich freshwater. Turbidity exhibits a bimodal oscillation with one peak during July (pre-monsoon) and another during December (NE monsoon). This is attributed to the relatively high phytoplankton density observed during pre-monsoon and heavy silt-laden freshwater influx during NE monsoon seasons. A significant positive correlation $(p \geq 0.01)$ between turbidity and chlorophyll has been observed and is testimony to the above observation during pre-monsoon period (Satpathy et al., 2010). Chlorophyll- $a$ values are found to be the lowest during November/ December (NE monsoon) and highest during August/ September (Southwest-Northeast monsoon transition). Relatively high concentration of chlorophyll- $a$ coincides with summer and pre-monsoon period, when relatively stable as well as optimal conditions of salinity, temperature, light, nutrient levels (conducive for production of copious amount of phytoplankton) prevails. Depletion of chlorophyll concentration during monsoon period is mainly associated with low saline, low temperature, low irradiance and high turbidity condition.

Nutrient concentrations in general show well pronounced seasonal variation mostly influenced by monsoonal rain. The two back waters, which are part of the ecosystem at this location, receive various wastes (domestic, agricultural etc.) from the nearby township and villages and thereby get enriched with nutrients. These backwaters get open to the coastal water during the NE monsoon period resulting in influx of the nutrient rich fresh water into the coastal milieu, which 
enhances the nutrient levels in the coastal water. Relatively low values are observed during premonsoon and post- monsoon period (April-August) which is attributed to their utilization by phytoplankton, as evident from the matching chlorophyll values during the same period. Increased levels of phosphate is also observed during September which has been associated with the phenomenon of upwelling, an event that generally occurs during pre-monsoon (August September) period along the Indian east coast (La Fond, 1957; De Souza et al., 1981; Ramaraju et al., 1992; Suryanarayan and Rao, 1992).

\section{Biofouling potential of Kalpakkam coastal waters}

A close perusal of literature on biofouling studies point that they have been triggered mainly based on two sound logics, such as scientific interest or technological need associated with maritime activities. The methodology such as, size of panel, duration of exposure, panel material, location of exposure etc used for biofouling studies largely remain similar by many workers. Researchers with academic interest look for ecological succession, species diversity, breeding pattern, seasonal variations, larval availability, climax community, that is more towards qualitative assessment and linking them with environmental factors. However, investigations with technological need look for quantitative assessment such as, biomass, \% of area coverage, density and occurrence interval. Notwithstanding the interest driven by either, the three important parameters for practical use undoubtedly are a) type of foulants, b) their growth rate and c) their seasonal variations, which decides the use of an economic and environment-friendly fouling control strategy. Biofouling problem is not only site specific, but also have been reported to be different for two different power plants drawing same source of cooling water (Karande et al., 1986), which has been attributed to different design and different material of use. An evaluation of composition and abundance of the fouling communities available in coastal waters provides an array of information particularly for the effective antifouling measures to be adopted in the cooling water systems.

In order to devise an effective biofouling control measure for Prototype Fast Breeder Reactor (under construction) cooling water system, it is essential to evaluate the present biofouling potential at Kalpakkam coastal waters. Considering a big hiatus lapsed between the last study (almost 20 years old) and the present need, a study was carried out with the following objectives; to find out a) the present seasonal settlement pattern of biofoulers, dominant species and breeding pattern, b) any change, as compared to that of earlier reported data and c) the role of physico-chemical characteristics of coastal water on biofouling. Moreover, this coast was severely affected by 2004 tsunami. Thus, the present study also brings out any change in settlement pattern, diversity, biomass and population density between pre- and post-Tsunami period.

\subsection{Material and Methods}

The present study was carried out between May 2006 to April 2007, in the coastal waters of Kalpakkam in the vicinity of MAPS. The study area is located at the intake of MAPS Jetty. Water depth at the study site is $\sim 8 \mathrm{~m}$. Teak wood panels (each $12 \times 9 \times 0.3 \mathrm{~cm}$ ) were suspended on epoxy coated mild steel frames from MAPS jetty. The panels were suspended at $1 \mathrm{~m}$ below the lowest low water mark, approximately $400 \mathrm{~m}$ away from the shoreline. Three series of observations (weekly, monthly and cumulative at $30 \mathrm{~d}$ intervals) were made. 
Weekly \& monthly observations were considered under short-term observations and cumulative was considered under long-term observation. Two unique features of this study are, for the first time a) fouling data at an interval of $7 d$ is available and b) photographs of each series are digitally available for future comparison. Different evaluating parameters viz. composition of organisms, number of organisms, growth rate, both $\%$ of number and $\%$ of area coverage, biomass (g. per $100 \mathrm{sq}$. $\mathrm{cm}$ ) were used to study the fouling pattern. Fouling concentration was assessed by counting the foulants available on the panels. Total biomass was calculated using a correction factor due to the absorption of water by the panels for specified time periods. The growth rate was recorded by measuring the size of macrofoulers. Apart from the above-mentioned parameters, diversity indices such as species diversity (D), species richness (R) and evenness (J) were also calculated following ShannonWeaver (1963), Gleason (1922) and Pielou (1966).

\subsection{Results}

\subsubsection{Fouling Community}

A list of organisms collected from test panels are given in Table 1. The total number of taxa involved in the fouling process at Kalpakkam coastal waters are found to be 30 during the present investigation.

\subsubsection{Biomass}

Biomass values of weekly panels ranged from 1-11 g. per 100 sq. cm (Fig. 6a). The lowest and highest biomass values for weekly panels were obtained in the months of November and December respectively. In the monthly observation, the lowest $(17$ g. per $100 \mathrm{sq} . \mathrm{cm})$ and the highest (46 g. per 100 sq. $\mathrm{cm}$ ) were observed in April and November respectively (Fig. 6b). In case of cumulative panel, a steep increase in biomass was observed from $28 \mathrm{~d}$ (77 $\mathrm{g}$. per 100 sq. cm), $56 \mathrm{~d}(97$ g. per 100 sq. cm), $112 \mathrm{~d}(185$ g. per $100 \mathrm{sq} . \mathrm{cm})$ to $150 \mathrm{~d}(648 \mathrm{~g}$. per 100 sq. $\mathrm{cm}$ ) (Table 2 ) onwards.

\subsubsection{Settlement pattern in short-term (weekly and monthly) panels}

A wide variation was observed in the number of settled organisms on weekly panels. Major fouling organisms observed were barnacles, hydroids, ascidians, oysters, sea anemones and green mussels. In addition to these sedentary organisms, some epizoic animals like errant polychaetes, flat worms, amphipods, crabs were also observed. Number of fouling organisms, number of species and \% of area coverage are given in Table 2.

\section{Coelenterata}

$\begin{array}{ll}\text { Campanulariidae } & \begin{array}{l}\text { Obelia bidontata Clarke } \\ \text { Obelia dichotoma Linnaeus } \\ \text { Clytia gracilis M.Sars } \\ \text { Aiptasia sp }\end{array} \\ \text { Aiptasidae } & \text { A }\end{array}$

Annelida

Nereidae

Pseudonereis anomala Gravier Platynereies $s p$ 
Serpulidae

Sabelidae

\section{Arthropoda}

Pycnogonidae

Balanidae

Corophidae

Amphithoidae
Serpula vermicularis Linnaeus

Hydroides norvegica Gunnerus

Daychone sp

Sabellistarte $\mathrm{sp}$

Pycnogonium indicum Sunder Raj

Balanus amphitrite Darwin

Balanus reticulatus Utonomi

Balanus tintinnabulum Linnaeus

Balanus variegatus Darwin

Corophium madrasensis Nayar

Corophium triaenonyx Stebbing

Paragrubia vorax Chevreux

\section{Ectoprocta}

Membraniporidae
Electridae

Mollusca

Mytilidae

Olividae

Ostreidae

\section{Menbranipora sp \\ Electra sp \\ Acanthodesia sp}

\section{Perna viridis Linnaeus \\ Perna indica Kuriaose \\ Modiolus undulatus Dunker \\ Olivancillaria gibbosa Born \\ Crassostrea madrasensis Preston \\ Ostrea edulis \\ Saccostrea cucullata Born}

\section{Didemnum psammathodes Sluiter}

Lissoclinum fragile Van Name

\section{Urochordata}
Didemnidae

Table 1. List of fouling organisms observed on the test panels suspended in the Kalpakkam coastal waters

The lowest and the highest numbers of foulants for weekly panels were 1 (November) and 136 per sq. cm (October) respectively (Fig. 6c). Fouling intensity was relatively high during summer and SW monsoon period, whereas during NE monsoon period, negligible intensity was observed. In monthly observation, the maximum (69 per sq. $\mathrm{cm})$ and the minimum (12 per sq. $\mathrm{cm}$ ) population density were obtained in September and January respectively (Fig. 6b). From July to September (SW monsoon) an increasing trend was observed, whereas from October onwards (NE monsoon) the fouling intensity started declining. Once again after January the fouling density was found to increase. This almost followed the salinity variation pattern observed for this coastal water. The percentage $(\%)$ of area coverage on weekly panels showed a well marked variation ranging between 0.08 and $100 \%$ (Fig. 6d), whereas, in case of monthly observation, it was found to be $89-100 \%$. In monthly observation, maximum area coverage $(100 \%)$ was found during July -August, November January and March (Fig. 6b). However, during weekly survey, maxima (80 - 100\%) were attained in August - September and November. 


\subsubsection{Variation in seasonal settlement of fouling organisms}

Barnacle: Among the different groups, barnacles were found to be the most dominant fouling community and its accumulation on the test panels was observed throughout the year. During the present study period, barnacles were represented by four species such as, Balanus amphitrite, B. tintinabulum, B. reticulatus and B. variegatus, which were found to be the most dominant on weekly (12.4 - 99\%) as well as monthly (5.9-85.2 \%) panels. On weekly panels, barnacle settlement was continuous with peaks observed during June-July and November -March. In case of monthly panels, large numbers were observed during July, November-December and March-April. During weekly and monthly observation maximum growth (size) obtained were $0.5-1 \mathrm{~mm}$ and 2-3 $\mathrm{mm}$ respectively.

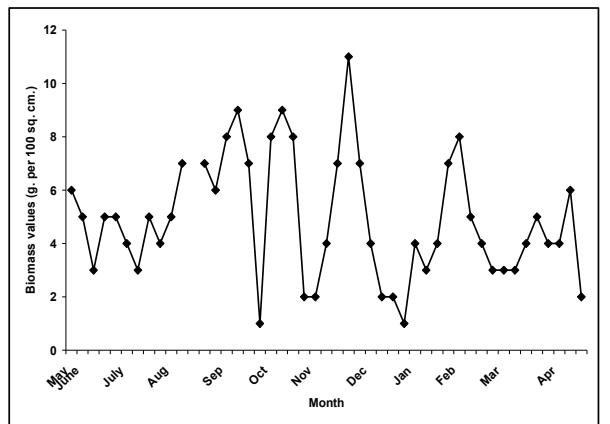

(a) weekly biomass

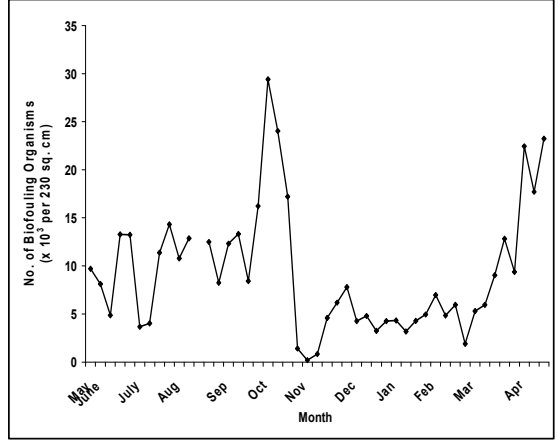

(c) weekly no. of organisms

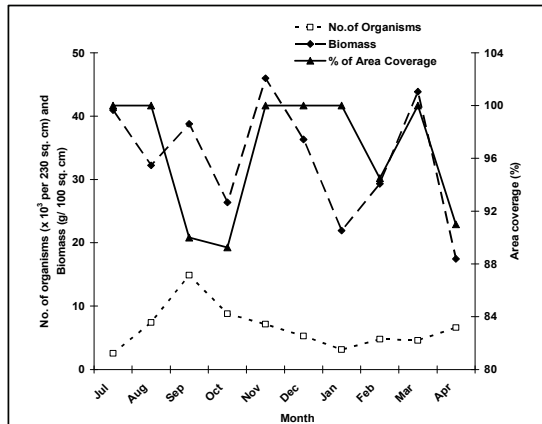

(b) monthly all three parameters

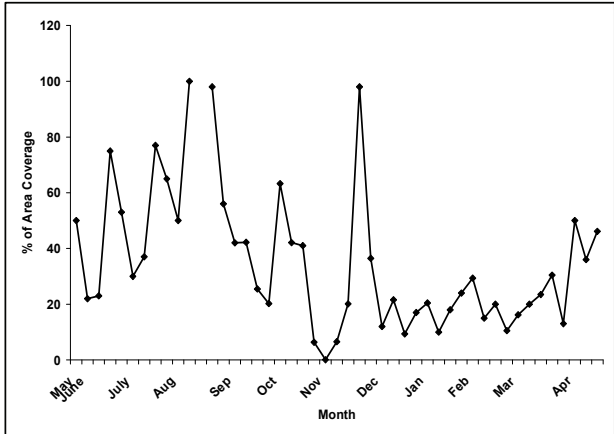

(d) weekly area coverage

Fig. 6. Variations in no. of organisms, biomass and \% of area coverage on weekly and monthly panels

Hydroids: Hydroids were only second to barnacles in abundance as well as seasonal occurrence and were dominated by Obelia sp. They started appearing on the panels after $5 \mathrm{~d}$ immersion. The growth of hydroids was recorded by measuring the length from base to tip. A maximum length of $5 \mathrm{~mm}$ on weekly panel and $17 \mathrm{~mm}$ on monthly panel was observed. Its \% composition varied between $0.64 \& 81.62 \%$ and $1.66 \& 37.28 \%$ during weekly and monthly investigation respectively.

Ascidians: Didemnum psammathodes and Lissoclinum fragile were the ascidian species encountered during the present observation. In the weekly observation, the occurrence of 
ascidians was generally restricted to March-April and June - August, with peak settlement during March-April. Monthly observation also depicted the dominance of ascidians during March-April and June-July, but with maximum density during June.

Sea anemones: Sea anemones, also a prominent group among the fouling assemblages, were represented by Sertularia sp., Aiptasia sp. in both weekly as well as monthly observations. They were found settling from Sepetember/ October onwards and formed a group particularly abundant during NE monsoon period. Their rate of growth was $1.5 \mathrm{~mm}$ diameter in $7 \mathrm{~d}$ and $8 \mathrm{~mm}$ diameter in $30 \mathrm{~d}$ observation and the settlement was relatively less during SW monsoon period.

Green Mussels: Green mussels (Perna viridis) were the most important constituent of the fouling community. They were mostly found attached to the mild steel frames during shortterm investigation and their absence was encountered during the entire weekly observation. However, during monthly survey, their \% composition varied from $0.08-11.02 \%$ and their colonization was generally observed during May-September with vigorous settlement during May-June and August - September.

\subsubsection{Seasonal settlement on long -term (cumulative) panels}

During the present observation, long -term panels were studied up to 150 days after which panels were lost due to entanglement of the frames and could not be retrieved. In the Kalpakkam coastal waters considerable settlement of barnacles, green mussels and ascidians were observed on the long-term panels. Apart from that, colonization of hydroids, oysters and sea anemones was also observed on the long-term panels. In addition to these sedentary organisms, epizoic animals like errant polychaetes, flat worms, amphipods, crabs were also observed. Peak settlement period of foulants, succession and climax community are represented in Table 2. Fouling succession was very prominent during the long-term observation as compared to weekly and monthly observation. Barnacles were the first to settle on the long-term panels and by the time they were of $14 \mathrm{~mm}$ in size, they were followed by hydroids and polychaete worms during the month of May. During this period, barnacle population remained largely unaffected by the secondary settlers. Ascidians began to colonize on the panels from June. Fully developed ascidian colonies completely covered the barnacles and other organisms by July and they remained till the end of August. Disappearance of ascidians was noticed from the month of September. Green mussels started appearing from August, whereas the peak colonization of mussels was observed from September onwards and it was maintained till mid-November.

Percentage composition of barnacles initially increased upto $56 \mathrm{~d}$ and subsequently reduced significantly on the long-term panels as follows $(15 \%, 28 \%, 13 \%$ and $5 \%$ on $28 \mathrm{~d}, 56 \mathrm{~d}, 112 \mathrm{~d}$ and $150 \mathrm{~d}$ old panel respectively). Green mussel, which was absent upto 28 days, started appearing subsequently and occupied $41 \%$ by $56 \mathrm{~d}$ and reached $90 \%$ by $150 \mathrm{~d}$. Accumulation of juvenile green mussels occurred after 28 days along with the pre-existing community consisting of barnacles, hydroids, oysters, polychaete worms, flat worms \& sea anemones. The mussels attained $0.5-1 \mathrm{~cm}$ in size by $56 \mathrm{~d}$ and from $112 \mathrm{~d}$ onwards, the panels were fully covered with adult green mussels of size $3-5 \mathrm{~cm}$. (Fig. 7). The relative abundance of fouling community observed for 28 d, 56 d, 112 d and 150d are given in Fig. 8. 


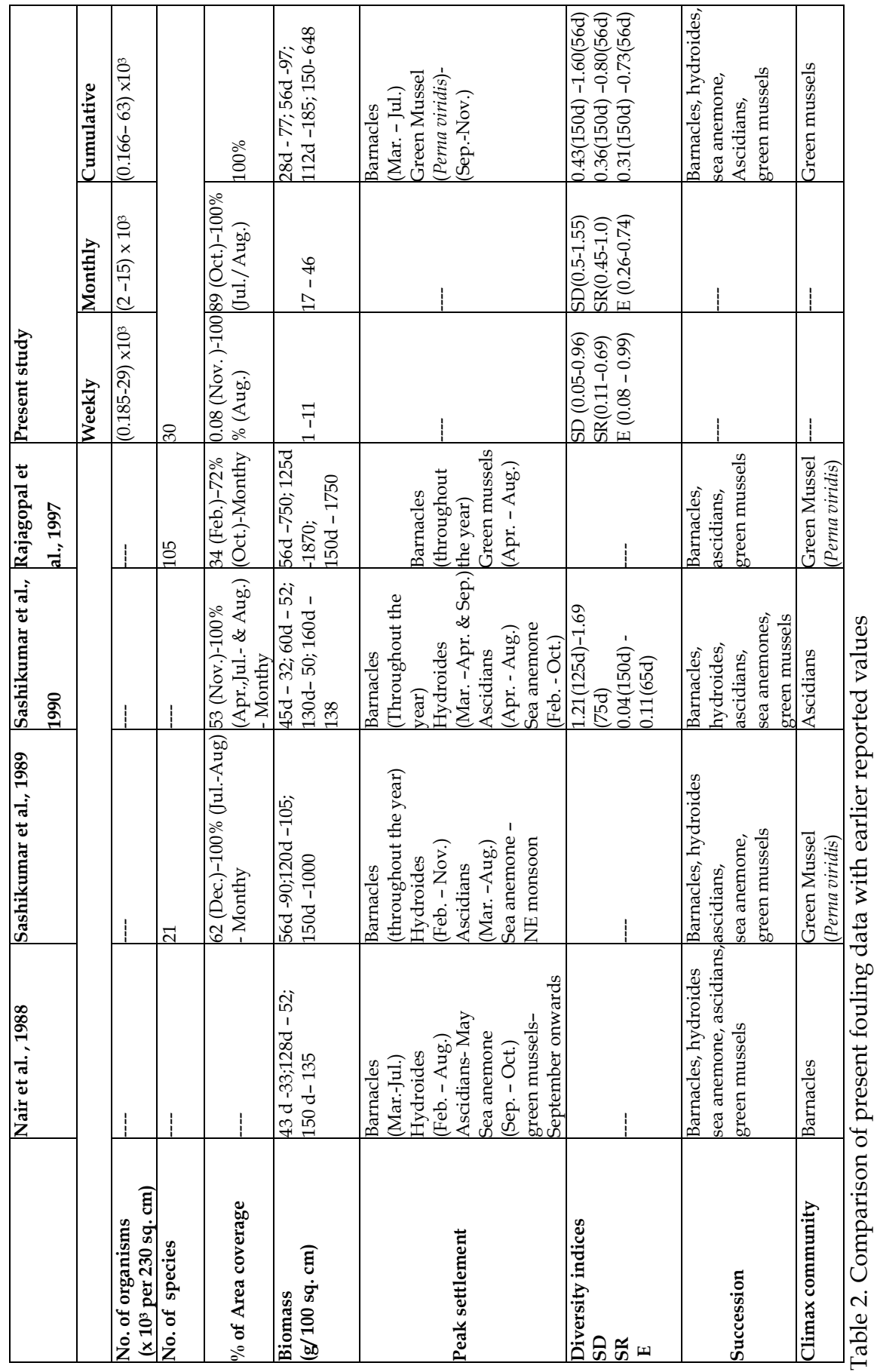




\subsection{Discussions}

\subsubsection{Fouling Community}

During the present investigation, the total number of fouling organism taxa observed at Kalpakkam coastal waters was 30, which is comparable with that of the observation of Sashikumar et al. (1989). However, Sashikumar et al. (1989) have observed presence of a few species of fishes, which were not encountered during the present study. Change in coastal water quality particularly the chlorophyll content may be one of the possible causes for such minor difference in fouling community. In contrast to the above, Rajagopal et al. (1997) have reported almost 3.5 times higher number of fouling species (105) than that of ours as well as that of Sashikumar et al. (1989) from the same location. In this regard, it is imperative to mention here that values with wide variations have been reported from both east and west coast of India. For example, 121 taxa from Visakhapatnam harbour, 37 taxa from Kakinada (Rao and Balaji, 1988), 42 taxa from Goa (Anil and Wagh, 1988) and 65 taxa from Cochin harbour (Nair and Nair, 1987) have been reported respectively. It is interesting to mention here that although Sashikumar et al. (1989) and Rajagopal et al. (1997) have studied from same location and during the same period, the no. of taxa observed by them differ substantially. Conveniently, Rajagopal et al. (1997) have neither discussed this aspect nor provided any plausible explanation for observation of such high no. of taxa as compared to that of Sashikumar et al. (1989).

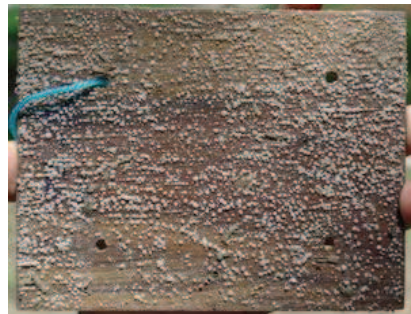

(a)

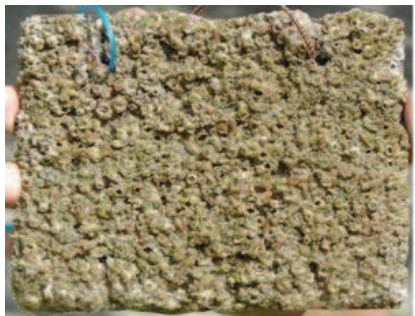

(b)

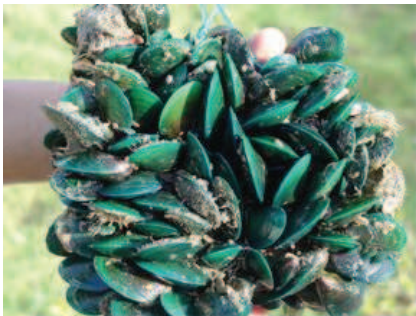

(c)

Fig. 7. A view of a weekly panel (a) A view of a monthly panel (b) A view of $112 \mathrm{~d}$ old panel, covered with green mussels (c)

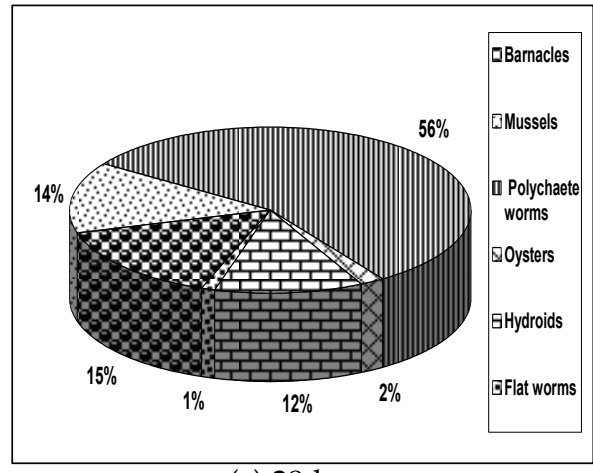

(a) $28 \mathrm{~d}$

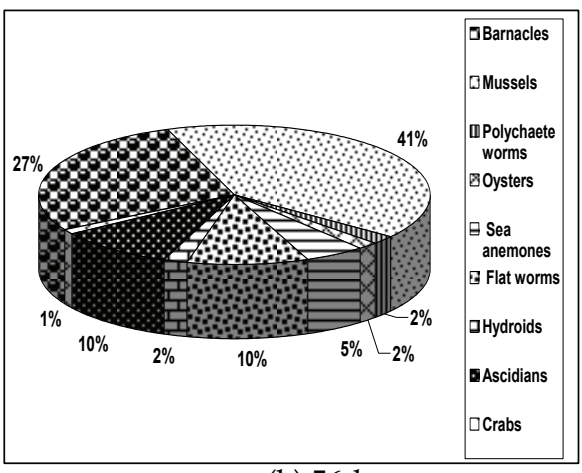

(b) $56 \mathrm{~d}$ 


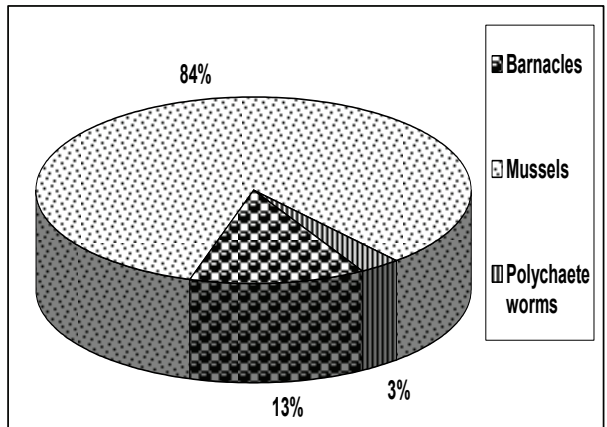

(c) $112 \mathrm{~d}$

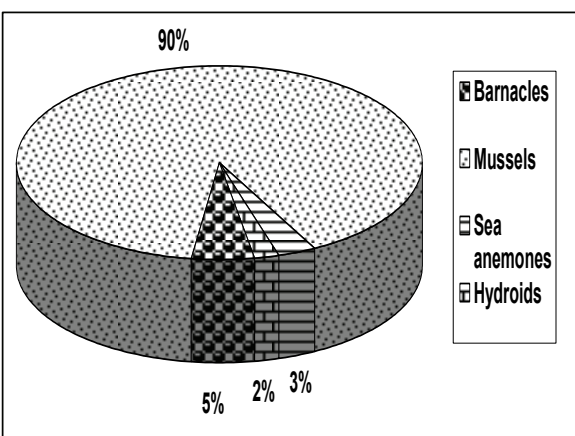

(d) $150 \mathrm{~d}$

Fig. 8. Relative abundance of fouling organisms for (a) 28 d, (b) 56 d, (c) 112 and (d) $150 d$ old panels exposed to Kalpakkam coastal waters

Although, direct comparison of the present observation with that of the earlier data is not justified on account of reasons, such as, differences in the exposure methodology, substratum and level of systematic identification, however, such wide variations as above observed by the three investigators (Present study, Rajagopal et al., 1997 and Sashikumar et al., 1989) from the same location under comparable conditions calls for further detailed investigations.

\subsubsection{Seasonal settlement pattern on short-term (weekly and monthly) observation}

The seasonal settlement of foulants in case of short-term panels was found to be quite different from that of the long-term panels, as described in the following discussion. The weekly panels showed well marked variation in population density of organisms. The lowest density was found during NE monsoon period, which could be due to the lowering of salinity level in the surface water during the above period. It is important to mention here that about $1000 \mathrm{~mm}$ of rainfall is received at Kalpakkam from NE monsoon. Moreover, with the onset of NE monsoon, the sea water current reverses from north to south as a result of which low saline riverine water from northern Bay of Bengal (BOB) (Varkey et al., 1996) coupled with the monsoonal precipitation deepens the salinity to the lowest during this period. It is known that salinity plays a crucial role in the growth, development and diversity of macro-foulants in the marine environment. Additionally, a relatively low temperature, which is not favorable for biogrowth was also prevailed during this period. It looks quite reasonable to speculate that substantial reduction in salinity and temperature along with enhanced suspended matter prevailed during NE monsoon period could have contributed for the low fouling density as well as low species diversity observed during this period. A relatively high fouling intensity on weekly panel was observed during summer and SW monsoon period. During this period, a comparatively high stable salinity, temperature and low turbidity prevailed, which is in general conducive for promoting large settlement of macrofoulants. This period also harvested highest number of phytoplankton count in this locality. The above observation was also substantiated by the positive correlation matrix value obtained between salinity \& fouling density $(p \geq 0.01)$ and chlorophyll/ phytoplankton density \& organism density ( $\mathrm{p} \geq 0.001)$ (Table 3). This showed that abundance of fouling organism at this locality was regulated mainly by two important factors namely, salinity and phytoplankton. Previous studies (Nair et al., 1988) showed peak settlement 
rates during May and June, whereas during the present study, an extension of this period up to September - October was observed. The present variation as compared to earlier could be due to the temporal variability in reproductive cycles, which was related either directly or indirectly to seasonal changes in the physical environment including temperature, salinity, phytoplankton productivity and light characteristics (Sashikumar et al., 1989). A close look at the present physico-chemical and biological characteristics of the Kalpakkam coastal water reveals substantial reduction in phytoplankton density, chlorophyll concentration and enhancement in suspended matter including that of nutrient in the recent past particularly after Tsunami (Satpathy et al., 2008). A detailed impact of Tsunami on the coastal milieu is reported elsewhere (Satpathy et al., 2008). Possibly these changes are also typified in the change in macrofoulant settlement pattern as observed during the present study. A significant difference was observed between successive weeks (Fig. 9), with respect to number of foulers, $\%$ of area coverage, growth rate etc. The selection pressure exerted by the ambiance itself on the recruitment of fouling organisms could be responsible for the above observation. In this context Sutherland (1981) states that, in natural habitats development of a fouling community is influenced by seasonal variations in larval recruitment, competition by dominant species and frequency of disturbance like predation. The variation in fouling density pattern in monthly panel almost followed the variability in salinity trend, which strengthened the fact that salinity is one of the major dominating factors responsible for fouling composition or settlement in the tropical coastal regions.

\begin{tabular}{|c|c|c|c|c|c|c|c|c|c|c|}
\hline Variables & $\begin{array}{c}\text { No of } \\
\text { organisms }\end{array}$ & Biomass & $\begin{array}{c}\% \text { Area } \\
\text { coverage }\end{array}$ & Temp & $\mathrm{pH}$ & Salinity & DO & Turbidity & Chl- a & $\begin{array}{l}\text { Phyto } \\
\text { density }\end{array}$ \\
\hline $\begin{array}{l}\text { No of } \\
\text { organisms }\end{array}$ & 1 & & & & & & & & & \\
\hline Biomass & 0.359 & 1 & & & & & & & & \\
\hline $\begin{array}{l}\% \text { Area } \\
\text { coverage }\end{array}$ & $0.504^{\mathrm{b}}$ & $0.518^{b}$ & 1 & & & & & & & \\
\hline Temp & 0.197 & -0.271 & -0.292 & 1 & & & & & & \\
\hline $\mathrm{pH}$ & -0.023 & $-0.475^{b}$ & $-0.432^{b}$ & 0.116 & 1 & & & & & \\
\hline Salinity & $0.515^{\mathrm{b}}$ & 0.047 & $0.452^{b}$ & 0.195 & -0.325 & 1 & & & & \\
\hline DO & -0.160 & -0.004 & -0.128 & $-0.381^{c}$ & 0.119 & $-0.430^{\mathrm{b}}$ & 1 & & & \\
\hline Turbidity & -0.090 & -0.065 & $0.445^{b}$ & -0.307 & -0.150 & 0.073 & -0.276 & 1 & & \\
\hline Chl-a & $0.458^{\mathrm{b}}$ & -0.098 & $0.502^{\mathrm{b}}$ & -0.016 & -0.259 & $0.685^{\mathrm{a}}$ & -0.332 & $0.423^{\mathrm{b}}$ & 1 & \\
\hline $\begin{array}{l}\text { Phyto } \\
\text { density }\end{array}$ & $0.442^{\mathrm{b}}$ & 0.139 & $0.465^{b}$ & -0.196 & -0.264 & $0.547^{a}$ & -0.145 & 0.355 & $0.839 \mathrm{a}$ & 1 \\
\hline
\end{tabular}

Table 3. Correlation between biofouling and hydrographical parameters

November (NE monsoon period) coincided with low intensity of biofouling for monthly and cumulative; however, \% of area coverage was found to be the highest during one of the weeks in November. Although, the highest \% coverage was observed during NE monsoon, a period of low salinity, however, both these parameters are positively correlated. Similarly, turbidity and \% of area coverage showed a positive correlation, in spite of the fact that high turbidity generally does not support abundant settlement. This contradiction can be argued out that, the period of low salinity and high turbidity was not favorable for settlement of most of the organisms. That is, the competition was almost nil and only organisms (barnacle and mussel), which can thrive well 
under the above environmental conditions grew fast and covered the entire area indicating a significant relationship between salinity and turbidity with \% of area coverage (Iwaki \& Hattori, 1987). Considering the fact that no weekly data was available from this location, this forms the benchmark for future reference as well as impact studies.

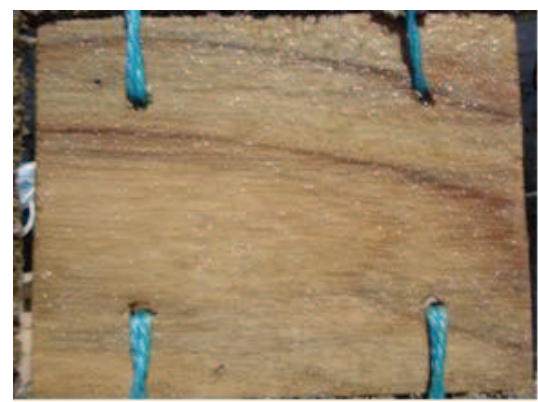

From $8^{\text {th }}-15^{\text {th }}$ June, 2006

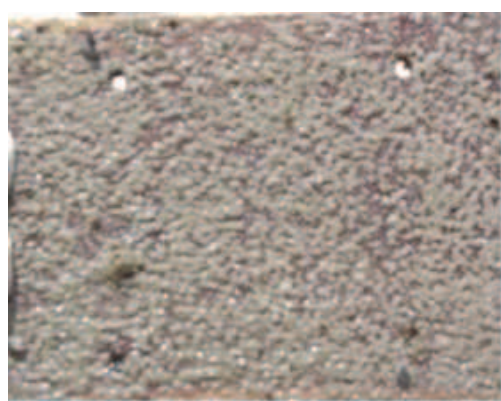

From $15^{\text {th }}-22^{\text {nd }}$ June, 2006

Fig. 9. Variations in fouling pattern observed on the test panels between two successive weeks

\subsubsection{Variations in seasonal settlement of fouling organisms}

Barnacles: Among the different groups of fouling organisms, barnacles are reported to be the most important group and all time breeders (Godwin, 1980; Nair et al., 1988). In the present study also, barnacles were found to be the most dominant fouler and its presence found throughout the year. Nair et al. (1988) and Sashikumar et al. (1990) have also reported the settlement of barnacles throughout the year at this location during the period 1986-87. On weekly panels, settlement was continuous with peaks during June-July and from November -March. Settlement of barnacle is known to be favored in illuminated area (Brankevich et al., 1988; Sashikumar et al.,1989; Rajagopal et al., 1997), notwithstanding the contradictory observation of Dahlem et al. (1984) and Venugopalan (1987). Considering the fact that southeast coast of India receives good illumination throughout the year, it is appropriate to assume from the present as well as earlier data that this would have supported the settlement of barnacle throughout the year on the test panel. In case of monthly panels, large numbers were observed during July, November-December and March-April. Although fouling density was high during September/ October, barnacle population was found to be the lowest in September. Settled green mussels (Perna viridis) prior to September established their dominance on the panel surface by September/ October, thereby not facilitating further settlement by barnacles. This could be the possible reason for relatively low settlement of barnacles during September. Dominance of other foulants over barnacles resulting in their population reduction has also been reported by Nelson (1981) on natural substrates. Territorial behavior of barnacles could also be another important cause of its population reduction during a particular period of the present investigation. It is reported that newly settled barnacles maintain a distance of $\sim 2 \mathrm{~mm}$ from the earlier settled barnacles or other settling organisms, which is known as 'Territorial behaviour' of barnacles (Crisp, 1961). As fouling density rises, the territorial separation gets weakened and as a consequence barnacle mass gets reduced (Crisp, 1961). The settlement pattern of barnacles during the present study showed similarity with the previous studies 
reported from coastal waters of southeast coast of India (Nair et al., 1988; Rajagopal et al., 1997). In contrast to the present study as well as that of Nair et al. (1988) and Rajagopal et al. (1997), relatively low barnacle population during June-July has been reported by Sashikumar et al. (1989). This disparity among different studies as far as peak settlement period of organisms is concerned, could be attributed to the variation in the influence of environmental parameters on breeding cycle of the organisms. The above agreement is strengthened by the fact that effect of array of environmental variables on reproduction cycle of different organisms greatly differs (Sutherland, 1981). Rajagopal et al. (1997) have reported six species of barnacle as against four observed by us. Possibly a long-term study would throw more light on this.

Maximum growth rate on weekly and monthly panel was observed during June and July respectively. This period was once again a period of stable salinity, temperature and nutrient, which was conducive for high growth. The present observation matches with those of Iwaki et al. (1977) in Matoya Bay and Sashikumar et al. (1989) from this locality. Although, Nair et al. (1988) have reported a relatively high growth rate as compared to the above report, however, the period of maximum growth rate matches with the present study. Hydroids: The peak settlement of this group was during July-August (SW monsoon) and January-March. The accumulation of this group was prominent on the edges of the panels. Selection of edges by the hydroids for their settlement could be due to the very location, which was found to be favorable for their filtration. On the other hand, had they settled on the panel surface, their growth would not have been faster due to crowding by other foulers. The present observation is found to be parallel with that of the findings of Nair et al. (1988) and Sashikumar et al. (1989). Interestingly, Rajagopal et al. (1997) reported peak settlement of hydroids during NE monsoon, an observation contrary to the present as well as those of Nair et al. (1988) and Sashikumar et al. (1989). NE monsoon period, a period of the lowest salinity, temperature and highest turbidity concomitant with low penetration of light, leads to lowest phytoplankton production. Under these conditions, settlement in general has been reported to be low to very low, and thus long-term studies again would provide a plausible answer to the above ambiguity.

Ascidians: Ascidians are a very important group of fouling organisms having a worldwide geographical distribution (Swami and Chhapgar, 2002). It has been reported that in temperate waters only a single generation is established each year, in contrast to two to four generations per year are established in tropical waters (Miller, 1974). During the weekly observation of the present study, the occurrence of ascidians was generally restricted to March-April and June - August, with peak settlement during March-April. Monthly observation also showed the dominance of ascidians in March-April and June-July, but with maximum density during June. This revealed that almost seven months in a year ascidians did not settle on the panel. In the south west coast of India (New Mangalore port), their appearance on the panel was also restricted only to 4 to 5 months in an year. Results of this study coupled with that of Khandeparker et al. (1995) clearly demonstrate that ascidians are a dominant group of macrofouling community in the Indian coastal water during premonsoon and late post-monsoon months. Such dominance of ascidians during a certain period of weekly and monthly observation could be attributed to the increased larval density \& their ability to undergo dedifferentiation and redifferentiation during that period (Sebastian \& Kurian, 1981). The ascidians dedifferentiate and form a heap of cells within a small ectodermal bag and when favourable conditions set in, the cells rebuild the tissues 
and redifferentiate into an adult ascidian (Khandeparker et al., 1995). Such interaction of the breeding period of foulants in the development of fouling communities has been reported by Chalmer (1982). Total absence of ascidians was encountered from September to December. This showed that early pre-monsoon to early post-monsoon period is not conducive for ascidian settlement at this coast. Even before the onset of NE monsoon, reversing of current (September/ October) from north to south takes place. This brings the low saline water from the north to the south and subsequently during NE monsoon period (October-January) salinity and temperature deep to the minimum till the end of January, the late-NE monsoon period. This clearly demonstrates that settlement of ascidians, highly dependent on salinity level. Similar observations have also been made by Swami and Chhapgar (2002). Although, they have reported the settlement of about 10 ascidian species, however, most of the ascidian species were absent during monsoon months. Ascidians have short larval life cycle lasting for a few hours and are very sensitive to minor variation in salinity content. Khandeparker et al. (1995) while studying the co-relation between ascidian larval availability and their settlement have clearly demonstrated that ascidian larvae were not available during monsoon and early post-monsoon in coastal water. Salinity, during monsoon period in Mangalore coastal water, decreased marginally ( $\sim 33 \mathrm{psu})$, whereas at this location it deeps significantly ( $\sim 25 \mathrm{psu})$. As a pure marine form, ascidians are not able to survive at low salinity (Renganathan, 1990). Thus, it was not surprising to observe total absence of ascidian on the panel during September-December period. Increased suspended load (during monsoon) and dominance of green mussels on panels (from September onwards) could be other important causes of disappearance of ascidian population (Khandeparker et al., 1995). The present trend in the settlement pattern of ascidians agrees with the studies by Sashikumar et al. (1989) and Nair et al. (1988). However, observations of ours as well as those of Nair et al. (1988) and Sashikumar et al. (1989) are not in tandem with that of Rajagopal et al. (1997), who have reported the presence of ascidians throughout the year including the unfavorable NE monsoon period.

Sea anemones: sea anemones are soft bodied conspicuous members of the marine fouling community. The observation of heavy colonization of sea anemone during September /October to NE monsoon period agrees with the earlier reports (Nair et al., 1988; Sashikumar et al., 1989; Rajagopal et al., 1997).

Green mussels: Green mussels (Perna viridis) are one of the most important constituents of the fouling community. The first peak of green mussel settlement coincided with the seasonal temperature and salinity maxima of the present study. Rajagopal et al. (1997) also reported the maximum $P$. viridis settlement during relatively high temperature and salinity condition. However, the second peak was observed corresponding to the maximum phytoplankton density and relatively high salinity during August-September, indicating the significant influence of the availability of food resources and salinity on the larval abundance and settlement of mussels (Pieters et al., 1980; Newell et al., 1982). Paul (1942) also recorded the settlement of this species in Madras harbor during March to November with a distinct peak during August - September. The trend observed on settlement of mussels corroborates the finding of Seed (1969) and Myint and Tyler (1982), who have explained in their classical papers on the role of temperature, salinity and food availability on mussel breeding periodicity.

Other fouling organisms: Other fouling organisms observed include bryozoans (Ectoprocta), oysters, polychaete worms \& flat worms etc and some other crustaceans such 
as, crabs (both larvae and juveniles), amphipods \& juvenile lobsters. Settlement pattern of bryozoans (Ectoprocta) did not show any definite trend in their temporal variation on shortterm panels. However, Rajagopal et al. (1997) have noticed bryozoan settlement during January - May, with peak colonization during February - March, when other fouling recruitment was less. Khandeparker et al. (1995) have reported heavy settlement of bryozoan during December-March from New Mangalore Port. The information available on the life history of bryozoan larvae in Kalpakkam coastal waters is at low key. Hence, to understand their indefinite trend, it requires more knowledge on their developmental biology. Appearance of juvenile oysters (Crassostrea madrasensis, Ostrea edulis) was observed in almost all the months, with peak settlement during August. However, during weekly survey they did not appear at all. The present study recorded considerable contribution (maximum, $\sim 7 \%$ ) by oysters to the fouling community during August on monthly panels, which has not been observed by other workers from this locality (Nair et al., 1988; Sasikuamr et al., 1989; Rajagopal et al., 1997). Price et al. (1975) have stated that the growth of oysters was the highest in August i.e. after their spawning, when glycogen reserves are restored. Growth ceases during winter, except in Florida, where growth was continuous throughout the year (Sellers and Stanley, 1984). It is interesting to note that stable environments inhibit better growth for oysters (Sellers and Stanley, 1984). We are unable to explain the cause of non-availability of oysters during earlier studies (Rajagopal et al., 1997; Sasikuamr et al., 1989; Nair et al., 1988). Though the peak settlement of polychaete worms (Serpula vermicularis, Hydroides norvegica) (0.05-2.1\%- Monthly and 2 - 56\% - cumulative) was observed in January during monthly observation, its availability as temporary settler was noticed during most part of the study period. Khandeparker et al. (1995) have also reported the year-round breeding activity of this organism from west coast of India. During the initial period of cumulative observation (28d), polychaete density was found to be dominant, which gradually disappeared during the subsequent days. Tube-dwelling polychaetes were found to have higher covering capacity than barnacles (Anil et al., 1990; Kajihara et al., 1976). Flat worms were found to be settled in relatively less numbers as compared to the other foulants during the entire short-term observation. Settlement of sponges, clams and snails were also occasionally noticed on the panels. Other crustaceans (amphipods, lobster juveniles, crab juveniles) started appearing from August onwards with high abundance during September. Despite, being a very significant component of the fouling assemblage in marine environment, macroalgae, showed its total absence at Kalpakkam coastal waters during the present investigation, which might have been due to competition for space, predation and grazing (Carpenter, 1990). Earlier workers too have not reported the settlement of macroalgae on the exposed panels from this locality.

\subsubsection{Seasonal settlement on long -term (cumulative) panels}

Long-term observation showed distinct fouling succession. To follow changes or succession occurring within the fouling community, cumulative/ long-term panels are more suitable than the short-term period (Rajagopal et al., 1997). Barnacles were found to be the first community settled on the long-term panels (maximum size $14 \mathrm{~mm}$ ). Hydroids and polychaete worms were the next to settle during the month of May. Barnacle population remained unaltered by the secondary settlers during this period. By June, ascidians started appearing on the panels and by July they fully covered the barnacles and other organisms. Sashikumar et al. (1990) have also reported the similar pattern of ascidian colonization on 
long-term panel. Thus, ascidians can be considered as a temporary 'stable point' in the fouling community development. According to Sutherland (1981), the term 'stable point' is to describe the succession of foulers. Disappearance of this group was noticed from the month of September, which could be due to the dominance of other fast growing foulers such as green mussels (Perna viridis). Sashikumar et al. (1989) also observed similar pattern of colonization on long-term panels.

During the present study, green mussel was found to be the climax community. This could be due to the fast growing and competitively superior green mussels establishing dominance on panel surfaces such that other fouling organisms are left with little space to settle. Richmond and Seed (1991) have also reported that competitively dominant species like green mussels are often successful due to their large body size, fast growth rate, extended longevity and prolonged larval life. According to the previous study by Rajagopal et al. (1997), the peak settlement of green mussels (P. viridis) occurred in April-June as well as one or two months immediately proceeding it. However, the present study showed that only from mid-July onwards mussels started appearing on the test panels and the peak was observed in September. It is apparent to assume that a shift in the peak settlement period of mussels has taken place, possibly due to the change in coastal water characteristics and the same could be confirmed over a long period of study. Surprisingly and interestingly both Nair et al. (1988) and Sashikumar et al. (1989) have not reported settlement of green mussel on their test panel, which is not in tandem with the observation of ours as well as that of Rajagopal et al. (1997).

\subsubsection{Biomass}

The lowest and highest biomass values for weekly panels were obtained in the months of November and December respectively, which could be attributed to the difference in peak settlement period of macrofoulants contributing more to the fouling biomass. In spite of the influence of NE monsoon, the highest value was observed during November (Monthly biomass) and December (Weekly biomass), which could be attributed to the elimination of most of the organisms due to unfavourable condition of the ambience (such as low salinity, high turbidity, low phytoplankton density leading to food scarcity etc) and survival of the most tolerant foulers (such as barnacles and green mussels). This exclusion of organisms leads to reduction in intra- and inter-specific competition, which ultimately facilitates the growth of better adapted foulants (Iwaki \& Hattori, 1987). Thus, barnacles and green mussels were found to contribute maximum to the total fouling biomass during the above period.

The abrupt increase in biomass in 150d old panel could be ascribed to the dominance of green mussels, $P$. viridis during the month of October. It is worth comparing the present data with those of Nair et al. (1988), Sashikumar et al. (1989) and Rajagopal et al. (1997) with respect to both short-term and long-term panels. Biomass observed on short-term panels (15-30d) exposed by Sashikumar et al. (1989) ranged from 1 to 7 g. per 100 sq. cm and Nair et al. (1988) under similar condition observed a biomass ranged from 9 to $51 \mathrm{~g}$. per $100 \mathrm{sq}$. cm. Karande et al. (1983) have reported 45 g. per 100 sq. cm biomass on 30 days exposed wooden panel from Kalpakkam coast. In contrast, Rajagopal et al. (1997) observed a biomass ranged from 130 to 640 g. per $100 \mathrm{sq}$. cm, a phenomenal increase. Such abnormal increase as above has not been explained by him as well as he has not compared his values with those of others. The present values ranged from 17 to 46 g. per 100 sq. cm (30d) and 1 to 11 g. per 100 
sq. cm (7d) compares well with Karande et al. (1983), Nair et al. (1988) and Sashikumar et al. (1989). A comparison of biomass values observed on long-term panels during the present study with that of the earlier studies (Table 2) are almost comparable with the values of Sashikumar et al. (1989). However, they marginally differ from that of Nair et al. (1988). On the contrary to all the above observation, Rajagopal et al. (1997) have reported significantly high biomass values. Reports of still higher values than that of Rajagopal et al. (1997) have been observed even from temperate waters (Trondheim, Norway - 760 g/ 100 sq.cm). It is worthwhile to mention here that such wide variations in biomass values could be due to an array of factors such as differences in exposure mechanism, substratum, time of exposure and dynamism of environmental variables, however, it needs further investigation to explain as to how such variations could be accounted scientifically.

\subsubsection{Diversity Indices}

The diversity indices showed wide variations between weekly and monthly surveys. During weekly observations, species diversity has shown its maxima (0.84) in the month of September and minima (0.32) in February. The highest value (0.41) and lowest value (0.11) of species richness was observed in the months of October and May respectively. The maximum and minimum values for evenness were 0.85 (May) and 0.32 (December) respectively. However, during cumulative observations the highest species diversity occurred on $56 \mathrm{~d}$ (1.60) panel and a steep reduction was noticed on $150 \mathrm{~d}(0.43)$ panel during which green mussels almost dominated the fouling community. Although, it is fairly logical to attribute the dominance of green mussels to the above observed low diversity value, the role of the competition among dominant species for space, predation \& grazing and survival of a superior \& better-adapted community by eliminating other species can not be ignored (Sashikumar et al., 1990). Such dominance of superior species appears to be a periodic phenomenon. Every species has a particular period of dominance, thus, no species can dominate the fouling assemblage for a very long duration. The significant reason behind this is the frequent variations in larval settlement and abundance in the open coastal waters (Raymont, 1983). Similar trend was also observed in species richness and evenness.

\subsection{Biofouling studies on metal panels}

Similar to that of the biofouling studies on the wooden panels, fouling studies on metal panels (SS 304, SS 316, mild steel, titamium, copper, aluminium brass, admiralty brass, cupronickel and monel) has also been initiated in order to find out the biofouling potential of these metals. Initial results showed maximum abundance of biofoulers on the Titanium panel $\left(7.9 \times 10^{3}\right.$ organisms per $222 \mathrm{sq}$. cm.) followed by Stainless steel (SS 316L) $\left(6.5 \times 10^{3}\right.$ organisms per $222 \mathrm{sq}$. cm.). Settlement of organisms was found to be minimum in case of aluminium brass and admiralty brass. Barnacles (Juveniles) were found very scarcely on $\mathrm{Cu}$ and $\mathrm{Cu}-\mathrm{Ni}$ panels. Biomass values were the highest for the Titanium $(28.7 \mathrm{~g}$. $100 \mathrm{sq} . \mathrm{cm}$.) and the lowest was observed in $\mathrm{Cu}(0.6$ g. 100 sq. cm.). In case of SS 316L, SS 304 L, Titanium, Monel and MS (Mildsteel) the \% of area coverage was found to be $100 \%$ and due to negligible settlement of organisms, area coverage was not considered for Admiralty brass and Aluminum brass panels. 


\section{Impact of biofouling on control strategy}

Selection of a suitable biofouling control strategy, particularly the chemical control methods, for a cooling water system mainly depends upon the physicochemical properties of the cooling water itself. Often, it has been found that the applied fouling control method becomes inefficient due to ability of the fouling organisms to alter the chemistry of the cooling water. The present study, carried out at MAPS is such a typical example which showed that a continuous monitoring of the cooling water at the outfall discharge is equally important as that of the intake water to find out the efficiency of the chemical control method (chlorination in this case). Studies with references to impacts of the activities of fouling organisms residing inside a cooling system on the cooling water quality are a few (Venugopalan and Nair, 1990; Satpathy et al., 1992; Satpathy, 1999, Satpathy et al., 2006; Masilamani et al., 1997). The intake tunnel works as a model to study the cooling water quality characteristics such as $\mathrm{pH}, \mathrm{DO}$, suspended matter, chlorophyll, nutrient etc as fresh seawater enters at one end (intake) and comes out at the other end (forebay) after passing through the tunnel with fouling organisms growing inside. A study was carried out to assess the impact of the activities of fouling community on the physicochemical properties of the cooling water in order to assess any possible interference in the operation and maintenance of the cooling water system.

\subsection{Methods}

All parameters were measured following standard methods as mentioned in section 3.1 of this chapter.

\subsection{Results and discussion}

The pre-condenser cooling water system of MAPS, comprising of the vertical shafts of intake \& forebay and the sub-seabed tunnel nurtures well-established fouling communities comprising of 49 species (Venugopalan et al., 1991) dominated by the green mussel Perna viridis and barnacles (Sashikumar, 1991). The green mussel alone accounted for more than 410 tonnes (Rajagopal et al., 1991) out of the total estimated biomass of about 580 tonnes (Nair, 1985) present inside the tunnel. This huge accumulation of biofouling organisms inside the tunnel affected the quality of water that passed through it by various activities such as consumption of oxygen \& detritus matter, release of faeces \& pseudo-faeces and excretion of ammonia etc. Although the tunnel was cleaned to the extent of $60-70 \%$ in 1987 , the present status is unknown.

An increase in $\mathrm{pH} \&$ turbidity and decrease in DO content was noticed in the forebay samples as compared to that of the intake. The $\mathrm{pH}$ values ranged from 7.68-8.30 and 7.76-8.30 in the intake and forebay respectively. The monthly average values showed marginally higher $\mathrm{pH}$ at forebay on most of the observations (Fig. 10a). The salinity values in the forebay compared to the intake samples was comparable. A significant increase in the turbidity was noticed in the forebay as compared to the intake. Values of turbidity ranged from 4.28-24.56 NTU and 6.1227.53 NTU in the intake and forebay samples respectively. The monthly average values of turbidity varied between $9.73 \pm 2.15-17.38 \pm 2.26 \mathrm{NTU}$ in intake and 11.10 $\pm 3.00-22.59 \pm 2.83 \mathrm{NTU}$ in the forebay (Fig. 10b). The increase in turbidity could be due to the excretion of the faecal matters by the biofouling community. However, the role of water velocity inside the tunnel, as high as $2 \mathrm{~m} \mathrm{sec}^{-1}$ could be a factor that causes the resuspension of the deposited sedimentary 
particles causing an increase in the turbidity. Similar increase in turbidity and suspended matter has been reported by Venugopalan \& Nair (1990) and Satpathy (1999) in the forebay samples. The role of suspended matter in the process of biofouling is crucial as it provides a large area to the bacteria and fungi for their growth (Bhosle et al., 1989) thereby enhancing the possibility of biocorrosion in the cooling system. The high siltation rate in the pump chambers in the forebay causing problems in smooth operation of the pumps is another effect of the suspended matter generated in the tunnel. Though, suspended matter contents in the coastal water in a long run could increase marginally, however it could reach equilibrium after a cycle is established. However, situation may change if a series of power plants are located at the same location within a short distance.

Decrease in the DO contents in the forebay due to its consumption by the residing biofouling community was one of the noteworthy features observed during the study, which corroborates the earlier studies made by Venugopalan \& Nair (1990) and Satpathy (1999). DO contents ranged from 4.37-6.34 $\mathrm{mg} \mathrm{l}^{-1}$ and $3.85-5.89 \mathrm{mg} \mathrm{l}^{-1}$ at the intake and forebay respectively (Fig. 10c). Its monthly average values varied between $4.72 \pm 0.29-6.06 \pm 0.50$ for intake samples and 4.51 $\pm 0.17-5.39 \pm 0.19$ for the forebay samples. The magnitude of difference of DO contents between the intake and forebay ranged from $0.1-1.1 \mathrm{mg} \mathrm{l}^{1-1}$. The wide variations of difference in DO concentration between intake and forebay could be due to the different flow rates of the seawater transported through the tunnel as has been reported earlier (Venugopalan \& Nair, 1990) and they have shown that the consumption of DO by the fouling organisms increased with increasing flow rate. Though the oxygen depletion has very little impact on power plant operation, this can be utilized as an advantage to kill the biofouling organisms residing the cooling water system. It has been reported that, during shut down conditions or at very low flow rate, the oxygen levels could come down to almost negligible amount (Satpathy, 1999; Satpathy and Nair, 1990). This process could be utilized to kill the settled organisms and clean the cooling water system.

Almost all the nutrients showed an increasing trend from intake to forebay during the present study however, they do not bear much significance towards biofouling control process. The ammonia, total nitrogen (TN), phosphate and total phosphorous (TP) concentrations were always higher in the forebay than that of intake whereas nitrate and silicate did not show any clear trend although most of the time forebay values were relatively high as compared to intake. Ammonia values increased from intake to forebay (Fig. 10d) and ranged from below detection limit (BDL)- $12.90 \mu \mathrm{mol} \mathrm{l}^{-1}$ and $0.06-10.42 \mu \mathrm{mol} \mathrm{l}^{-1}$ in the intake and forebay samples respectively. The increased level of all the nitrogenous nutrients in the forebay could be due to the fact that all the organisms produce reduced nitrogen compounds as byproducts of the metabolic activities and released to the environment by excretion (Chen et al., 1994). Further, the increase in ammonia contents in the forebay could be attributed to its generation as the chief excretory product of marine invertebrates (Clarke et al., 1994). Experiments by Masilamani et al. (2001) has shown that at normal temperature and salinity conditions, the quantity of ammonia excreted is about $5 \mu \mathrm{mol} \mathrm{l}^{-1} \mathrm{~h}^{-1}$ induvidual ${ }^{-1}$ for a size group of $8-9 \mathrm{~cm}$ of Perna viridis, the chief macrofoulant in the MAPS tunnel. Ammonia is well known to accelerate the corrosion rate in copper based alloys used as condenser tube material in power plants (Rippon, 1979). The presence of ammonia in substantial quantity and on continuous basis in the cooling water system could be detrimental for the durability of aluminum brass condenser tube of MAPS. Also, the efficiency of chlorine, used as the biocide to control the biofouling in a cooling water system, gets reduced in presence of ammonia due to its reaction with chlorine to 
form chloramines. These chloramines are about 200 times less effective than free chlorine (Venkateswarlu, 1990) as antifouling control measure. Moreover, chloramines are relatively stable compound and are toxic to fishes at concentrations > $0.1 \mathrm{ppm}$ (Brungs, 1973). Thus, presence of fouling organisms inside a cooling water system not only affects directly the performance of cooling water system but also has deleterious impact indirectly in variety of ways. Therefore, biofouling control is essential even when it does not affect the cooling water system directly.

A significant decrease in the chlorophyll- $a$ concentration was observed in the forebay samples (Fig. 11). The decrease in the chlorophyll- $a$ content could be due to the consumption of the phytoplankton by the biofoulers, which are filter feeders. Moreover, chlorination also accounts for this decrease in chlorophyll- $a$ contents in the forebay water as this biocide is used for the control of biofouling. Earlier studies (Satpathy, 1999) at the same locations also depicted similar trend by this photosynthetic pigment. This is further supported by the studies of Saravanane et al., 1998; Venugopalan and Nair (1990) and Sahu et al. (2006), which showed an expected decrease in phytoplankton density at the forebay compared to the intake point.

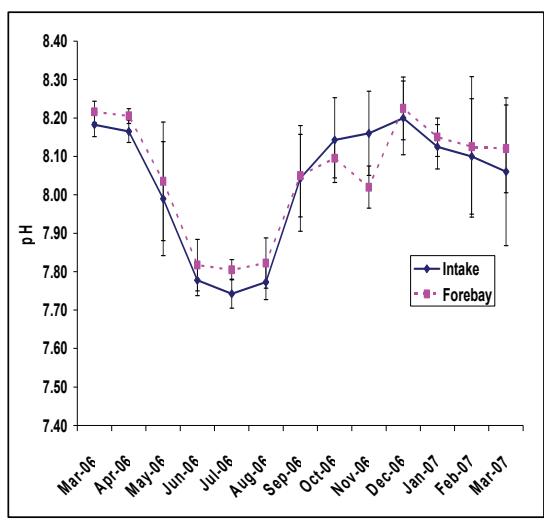

(a)

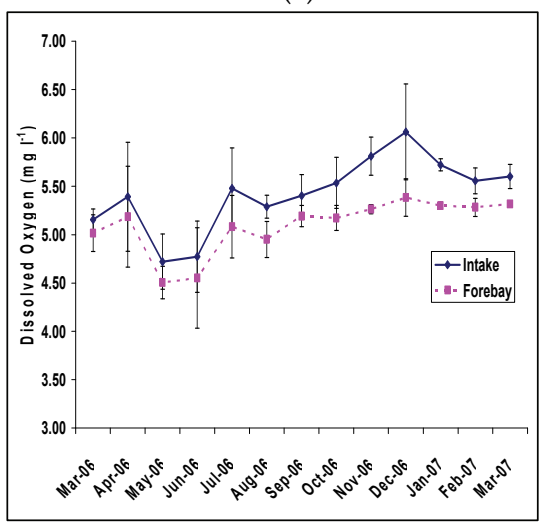

(c)

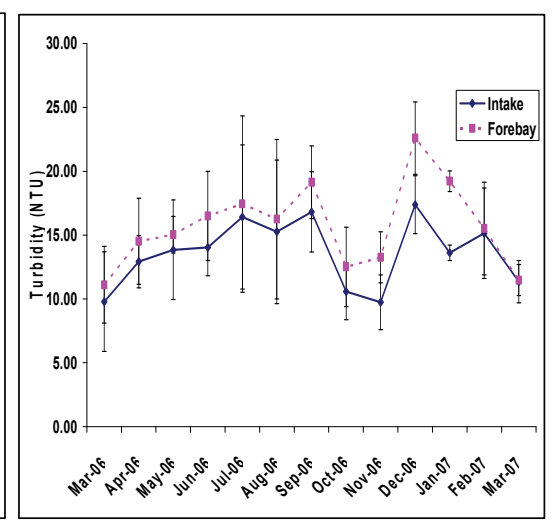

(b)

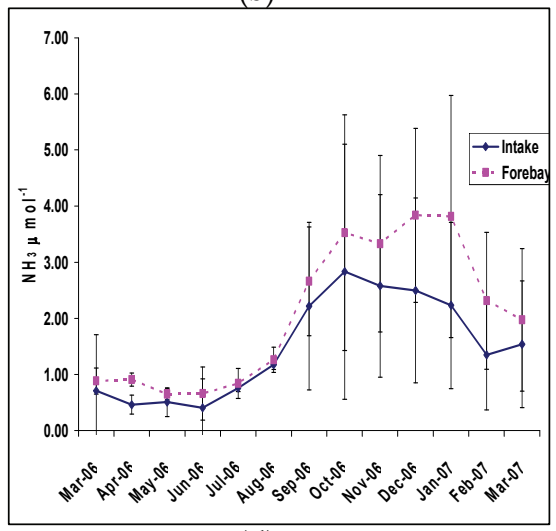

(d)

Fig. 10. Monthly variations in $\mathrm{pH}(\mathrm{a})$, turbidity (b), dissolved oxygen (c) and ammonia (d) at intake and forebay of MAPS 


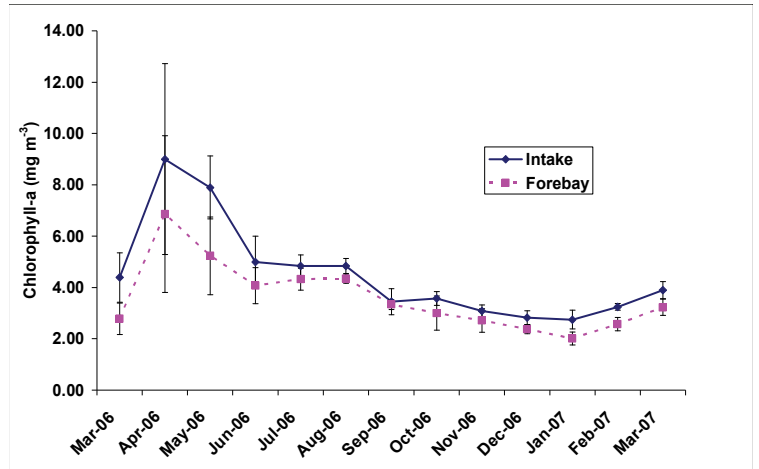

Fig. 11. Monthly variation in chlorophyll-a at intake and forebay of MAPS

\section{Biofouling control}

The principal objective of biofouling control technique is to prevent the aquatic organisms from growing to sizes large enough to cause flow degradation. Most control strategies are designed to treat the larval and juvenile stages of fouling organisms, although some of these strategies are effective against adults as well. Owing to the complexity of the nature of aquatic life, which colonizes a submerged surface, a general solution to biofouling problem is not feasible. Selection of control measures is governed by many factors; viz: efficiency, cost \& environmental acceptability. Biofouling control by manual cleaning of power plant cooling circuits is difficult as well as uneconomical. Although methods like Amertap, spongeball, screens of various sizes, heat treatment and different biocides are in use for prevention and control of biofouling, chlorination stands out as the most widely used and efficient method owing to its proven effectiveness, easy availability and relatively low cost. Chlorination of cooling water was first tried in the United States in 1924 at the Commonwealth Edison Company's Northwest Station on an experimental basis to combat biofouling. These formal experiments showed that chlorination would prevent biofouling. Over the years chlorination has been accepted as the most widely used biocide for biofouling control. However, recently implemented Environmental Protection Agency (EPA) and state limitations on allowable chlorine discharges in plant effluents have become a stumbling block in chlorination practices (Satpathy, 1990). This restriction has caused the utilities to seek alternative treatment methods and methods to minimize chlorine discharges. Although this chapter deals with, in detail chlorination aspects in biofouling control in power plant cooling water system, however, some of the alternatives to chlorination are also discussed below.

\subsection{Physical methods}

Physical methods are adopted essentially to prevent the entry of macroorganisms of certain size into the cooling conduits (Whitehouse et al., 1985). Screens of various mesh size (10 mm - UK and Japan, 4mm - France and Italy, 4 to $10 \mathrm{~mm}$ - Netherlands and 10 to $25 \mathrm{~mm}$ - India) are used at different locations like intake point and pump house to act as a first line of defence against large debris, seaweed, fishes jelly-fishes mussel clumps, barnacles, fishes, \& other macro organisms (Satpathy, 1990). The use of screen themselves cause sometimes 
problem as they become blocked by seaweed or Jellyfishes etc. Although, it prevents the entry of macro organisms, it cannot prevent entry of tiny larvae and thus the growth inside the cooling system.

\subsection{Flow}

The relative motion between cooling water and the substratum also determines the type and extent of fouling settlement. At high flow-rates the shear stress of the water often exceeds the shear strength of many organisms and this mechanism is used to control biofouling (Satpathy, 1990). For example in Italy at Vado Ligure, the cooling water intake of a power plant (1320 MW (e), four $2.2 \mathrm{~m}$ dia culverts of 1400-1500 m long) was kept fouling-free for 14 years by maintaining a velocity of $11 \mathrm{ft} / \mathrm{sec}$ (Whitehouse et al., 1985). Flow rates of 2.5-3.0 $\mathrm{m} / \mathrm{s}$ will be necessary to prevent settlement of mussels, but already settled mussels are not detached at these flow rates. Moreover, it is operationally difficult to maintain such constant flow as above without any hiatus. Thus, during low flow or shutdown period, the settled organisms could not be detached even at higher flow than the above.

\subsection{Heat treatment}

It is well known that response of biological systems to temperature is very pronounced. Though metabolic activity increases with temperature up to a certain temperature, once the optimum temperature is surpassed metabolic activity of nearly all organisms gets affected adversely (Masilamani et al., 2002). Taking advantage of this temperature and metabolic activity relationship, biofouling control methods based on temperature changes have been used in power plant cooling systems (Whitehouse et al., 1985). This method is routinely used in a few plants in USA, England, Italy, Netherland and Russia. Heat treatment for macrofouling control has been used for biofouling control (Fisher et al., 1984). Here the heated effluent from the condenser is diverted through the intake tunnel which when passed through the condenser picks up more heat. By manipulation of this heated water through different parts of the cooling system for a specified period, killing of the biofoulants is achieved. It appears that $40^{\circ} \mathrm{C}$ for one hour is enough to eliminate mussel and other fouling organisms. The duration and temperature is given by the equation below.

$$
\mathrm{T}=50-2.46 \ln \mathrm{t}
$$

( $\mathrm{T}=$ temperature $\left({ }^{\circ} \mathrm{C}\right)$ required to kill the foulants during heat treatment period of ' $\mathrm{t}$ ' minutes)

The disadvantage of this treatment are (a) power station has to operate at reduced power level during the period of treatment (b) this cannot be tried in existing power station where the system is not designed \& (c) it cannot control slime in the condensers. Since it has been proved economical in temperate countries, it should be more economical in tropical countries wherein the organisms are already living close to their lethal temperature limit. However, it has not been popular ever since its inception possibly. In this method the organisms are killed rather than controlled, thus ecologically not benign. 


\subsection{Mechanical methods}

Both manual and mechanical methods such as Taprogge, Amertap system and MAN system (Satpathy, 1990) have been used to keep microfouling under control. In all these system scouring action of sponge rubber ball or MAN brushes clean the condenser tubes when passed through it intermittently or continuously. These methods have not been popular as they are only useful for microfouling control in condenser section and moreover, its cost is prohibitive.

\subsection{Osmotic control method}

Most marine organism cannot tolerate salinity below 3 ppt (Satpathy et al., 1999) and below this salinity they are killed. Therefore settlement of marine organisms on cooling conduit surfaces can be controlled by varying the salinity.

\subsection{Bromine based compounds}

Chemistry of bromine has proved beyond doubt that bromine in different forms could be a simple, cost effective alternative to chlorination for biofouling control (Satpathy, 1990). Although bromine is delivered in different practical forms, it is the hypobromous acid $(\mathrm{HOBr})$ which is formed during hydrolysis that is responsible for the biocidal action. Bromine chloride is more attractive as a biocide because of the following advantages: (i) rapid residual decay benefits the environment and also causes lower condenser corrosion rates, (ii) high solubility, (iii) high density that permits large amounts of liquid $\mathrm{BrCl}$ to be supplied in small container, (iv) viability in a broad temperature and $\mathrm{pH}$ range, (v) it is more economical if the cost of maintaining EPA regulation of discharge limit is taken into account.

\subsection{Ozone}

Ozone is well known for its value as a bactericidal agent (Nair et al., 1997). It is an extremely strong oxidant compared to chlorine. It is very effective due to its high oxidation potential. It is also less toxic and less persistent than chlorine. Unlike chlorine it does not contribute to the chloride content of the cooling water nor does it generate undesirable byproducts and therefore, is environmentally more acceptable. The potential of ozone for biofouling control has been tried at Public Service Electric \& Gas plant, New Jersy sites. Disadvantages like (i) difficulty to achieve uniform distribution, (ii) high ozone demand in presence of bromide as well as in polluted water, (iii) ozoniser occupying large space (lack of compressibility) \& necessity for on-site generation and (iv) high cost have restricted the use of ozone largely for treatment of potable water and sewage in Europe. Moreover, there is very little information available on the possible corrosion of condenser tubes. Like chlorine ozone also is affected by $\mathrm{pH}$, temperature, and organics.

\subsection{Bioactive compounds}

There may be no greater way to fight nature than with nature itself; it is important to study fouling organisms biology in order to help prevent them from becoming a nuisance. Nemertine pyridyl alkaloids (chemical compounds from worms) may be used for the inhibition of Balanus amphitrite (barnacle) larvae. Studies in Caribbean sponges have shown that purified, extracted compounds from them deter bacterial attachment. Since bacterial 
attachment is often the initial step of the biofouling process, these sponges and their chemistry may help to prevent the succession to larger organisms. A member of the ascidian group, Distaplia nathensis, is also showing promise - used in an extract, it inhibits byssal production in the mussel Perna indica (Murugan and Ramasamy, 2003). A byssus is a mass of filaments which the mussel uses to attach itself to a surface. Dark brown bacteria provide the best attachment for oyster larvae, but there are other bacteria which produce polysaccharides that are toxic to oysters; in other words, they may be used to prevent biofouling by oysters. Immunoglobulins provide a natural biocide for planktonic and sessile bacteria. Some species of bacteria can be used against other biofouling organisms. Pseudoalteromonas spp., marine bacteria, produces bioactive compounds with an inhibitory effect and can be used to prevent biofouling by algae like Ulva lactuca and by barnacles like Hydroides elegans and Balanus amphitrite. Extensive research is still needed to determine the exact method of applying this knowledge.

\subsection{Other control agents}

Iodine, hydrogen peroxide, potassium permanganate and iron (VI), chlorine dioxide etc have been tried however, due to one or the other reason (no information on toxicity to aquatic life, corrosion aspect, and economical aspect); they have not been popular in power plant cooling system. Antifouling coatings made up of organometallic compounds and copper oxide and other types of paints have also been tried in power plant cooling systems for biofouling control. Commercial cuprous oxide formulation must provide a leach rate of $10 \square \mathrm{g} \mathrm{Cu} \mathrm{cm}^{-2}$ day-1 $^{-1}$ (Little and De Palma, 1988). However, the highly toxic nature of paints like Tributyl tin oxide with leach rate of 1-5 $\mu \mathrm{g} \mathrm{Sn} \mathrm{cm}^{-2}$ day $^{-1}$, which leads to reversal of sex, "imposex" in some aquatic organisms, has led to ban of metal based paints giving rise to the demand of low surface energy silicon based paints. Copper has not been popular due to high cost, operational difficulty and short life span. Acrolein, an effective antifouling agent but is expensive, highly toxic and also highly flammable (Satpathy, 1990).

Settlement of fouling organisms in the seawater intake tunnel is generally controlled by chlorination $(\sim 0.5 \mathrm{ppm}$ residual). However, when the tunnel is ready and waiting for the chlorination plant to become operational, which generally extends from a few months to a year or two, there is a need to keep the tunnel free from fouling during this period. Thus, antifouling coating could be the only plausible method to combat fouling inside the tunnel/pipe, conveying cooling water from intake to pump house, during this gestation period. In view of this, a study was carried out to screen three different antifouling paints (Nukote, Paint-2 and Sigma Glide), for their biofouling control potential with the objective of assessing temporal variations in settlement pattern, growth rate, biomass and area coverage by fouling organisms. The results of three different proprietary antifouling paints which were assessed for their biofouling control potential in PFBR tunnel are given below. Panels were exposed to coastal waters by suspending them from MAPS jetty and were retrieved after a specified time. During each retrieval total biomass, type of organisms settled and area coverage were assessed (Table 4).

\section{Important observations}

- The Nukote paint was found more prone to biofouling and the attachment of organisms was found to be with strong adhesiveness as compared to other two paints. The area coverage attained $100 \%$ just after a period of 17 days of exposure and the panel remained fully covered throughout the 5 months study period (Fig. 12). 
- Bio-growth on Paint-2 was found to be relatively less as compared to that of the Nukote paint and $100 \%$ area coverage was observed only after 66 days of exposure. Biomass was found to be relatively low in almost all the observations as compared to that of the Nukote paint. The area coverage reduced significantly from about $95 \%$ on $37^{\text {th }}$ day to about $40 \%$ on $45^{\text {th }}$ day (Fig. 12). This was due to the easy peeling off of the organisms from the panel surface. One of the most important observations was that barnacles grew on the base metal of the panel by penetrating the paint coating (Fig. 13) and thus adversely affected the panel integrity.

- Rate of bio-growth on Sigma Glide was the highest as compared to the other two paints. However, it showed a unique behaviour of detachment of organisms very easily as compared to the other two paints (Fig. 13). The area coverage did not attain $100 \%$ during the 35 days of study. This indicated that, the adhesiveness of organisms attached to the panels coated with paint- 2 and Sigma Glide was relatively weak. Thus it would get peeled off in a dynamic cooling water system (during flow) and as well as in presence of chlorine.

From the above observations it was concluded that Sigma Glide showed promising positive results for its use against biofouling in a typical cooling water system (tunnel) for a limited time period.

\begin{tabular}{|c|c|c|c|c|c|c|}
\hline Day & \multicolumn{3}{|c|}{ Biomass (g/ 100 $\left.\mathbf{~ c m}^{2}\right)$} & \multicolumn{3}{c|}{ Area coverage (\%) } \\
\hline & Nukote & Paint-2 & Sigma Glide & Nukote & Paint-2 & Sigma Glide \\
\hline 7 & & & & 25 & 15 & 25 \\
\hline 15 & 11.1 & 8.0 & 8.8 & 90 & 60 & 50 \\
\hline 31 & 18.7 & 18.4 & 45.4 & 100 & 80 & 90 \\
\hline 37 & 19.7 & 16.7 & 54.6 & 100 & 95 & 90 \\
\hline 45 & 19.0 & 15.8 & & 100 & 40 & \\
\hline 52 & 18.7 & 9.8 & & 100 & 60 & \\
\hline 66 & 41.0 & 41.0 & & 100 & 100 & \\
\hline 80 & 26.3 & 34.3 & & 100 & 70 & \\
\hline 108 & 27.3 & 36.0 & & 100 & 90 & \\
\hline 122 & 33.2 & 45.0 & & 100 & 40 & \\
\hline 150 & 68.2 & 76.6 & & 100 & 70 & \\
\hline
\end{tabular}

Table 4. Temporal variations in biomass and area coverage of biofouling organisms on panels coated with different antifouling paints

The adverse effects of ionising radiation on biological systems were evident since its discovery (Satpathy et al., 1999). Therefore, attempts were made to dope radioactive materials into antifouling coating. Studies carried out using Thallium-204 radioisotopes demonstrated significant antifouling capability of this material. However, the dosage required (20 rads/h) was considered to be too high for comfortable handling by untrained operators (Satpathy, 1990). Nuclear power plants, which have highly trained operators in handling radioactive materials, could consider this as a viable technique for control of biofouling. 


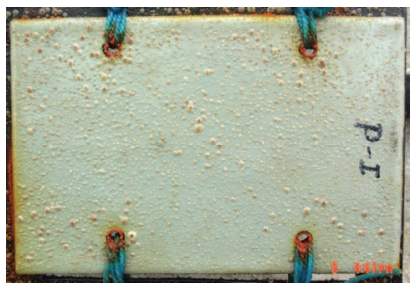

After 7 days

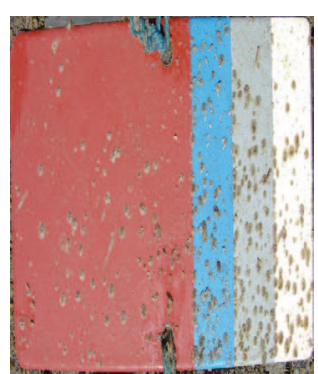

After 7 days

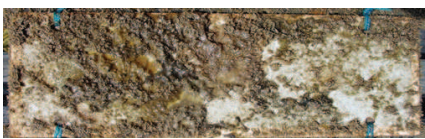

After 39 days

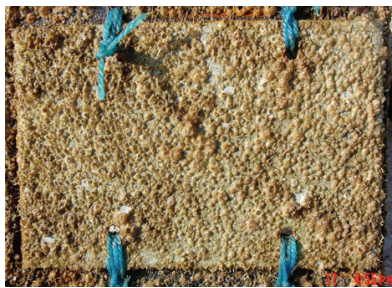

After 15 days

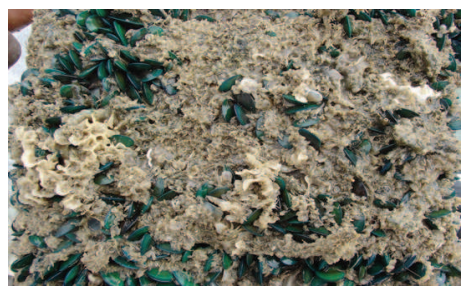

After 151 days

Nukote

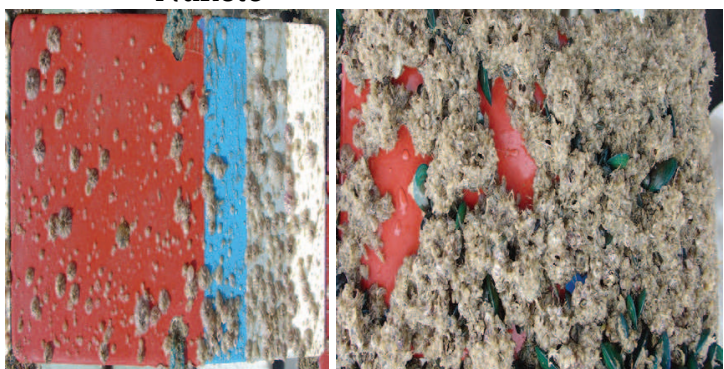

After 15 days

Sigma Glide

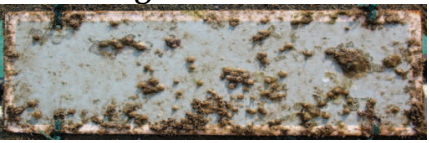

After 45 days
After 35 days

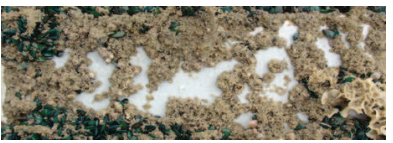

After 151 days

Paint-2

Fig. 12. Growth of fouling organisms on panels coated with antifouling paints with different exposure periods

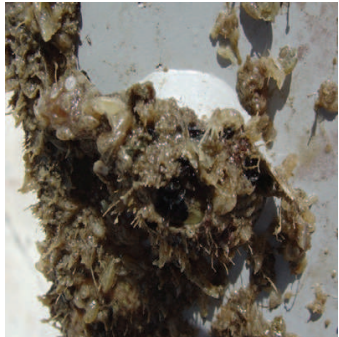

(a)

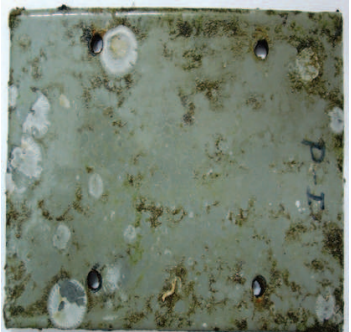

(b)

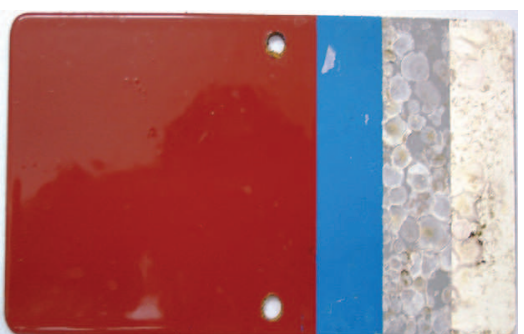

(c)

Fig. 13. (a) Penetration of barnacle through the paint coating (Paint-2), (b) after removal of bio-growth (Nukote-151 days old) and (c) After removal of bio-growth (Sigma Glide-35 days old)

\subsection{Chlorine}

Although alternative biocides are available, chlorine still remains the most common method for biofouling control in cooling water systems and is often preferred to others because of its 
proven effectiveness, easy availability and relatively low cost. An approximate comparison of cost difference of biocides has been made and given in Table 5. It is used to overcome both slime in the condenser and macrofouling in the pre-condenser sections. However, the exact mechanism of biocidal action of chlorine or any other oxidizing biocide still remains an academic puzzle. Theories proposed by various workers have been described in detail by White (1972) and Rippon (1979). The basic principle is when an oxidizing agent diffuses through the cell wall of an organism, it oxidizes the enzyme groups preventing further metabolic activity and thereby bringing about death to the organism. In case of macroorganisms the death is brought about by the reduction in growth by means of decrease in filtration rate and consequent decrease in food availability combined with pathological effects (Masilamani et al., 2002).

Both microfouling and macrofouling can successfully be controlled by intermittent and low dose continuous chlorination respectively. Although, environmental stipulations due to the toxic effects of the by-products formed during chlorination are some of the recent barriers for its continuance, it has also safety problems currently encountered particularly with respect to its operations. Chlorination has not been fully successful as safety associated with transport; storage \& handling of chlorination plant have come in its way. To overcome this, in-situ generation of chlorine by electro-chlorination has come very handy to power plant authorities. In this process according to the need chlorine is generated at the cooling water intake site and added then and there. A few plants in India (Tata Thermal, Mumbai, \& NTPC, Viskhapatanam) have adopted this state-of-the-art mode and are successful in smooth operation of chlorination plant. In addition, uniform distribution has been another problem and needs an R \& D effort to design such system. Although, it is easier said than done, a good amount of R\&D work is essential before a precise chlorination regime is put into pragmatic use. This section discusses in details the chemistry of chlorination such as chlorine demand, chlorine decay, break point chlorination, speciation of chlorine residual and role of temperature and ammonia on chlorination in biofouling control. Moreover, targeted chlorination is also discussed briefly.

\begin{tabular}{|l|l|}
\hline Chlorine (gas) & 1 \\
\hline Chlorine (electrochlorination) & 2.5 \\
\hline Sodium hypochlorite & 5.0 \\
\hline TBTO & 0.8 \\
\hline Tin & 0.2 \\
\hline Ozone & high \\
\hline Bromine chloride & 2.5 \\
\hline Chlorine dioxide & 5.0 \\
\hline Chlorinatated Bromide salt & 10.0 \\
\hline Organic biocides & very high \\
\hline Iodine & 40.0 \\
\hline
\end{tabular}

Table 5. Cost comparison of different biocides (arbitrary units)

\subsubsection{Chemistry of Chlorination}

Chlorine when added to water almost instantaneously forms hypochlorous acid ( $\mathrm{HOCl})$. 


$$
\mathrm{Cl}_{2}+\mathrm{H}_{2} \mathrm{O}<=>\mathrm{HOCl}+\mathrm{HCl}
$$

This $\mathrm{HOCl}$ is largely responsible for the biocidal action of chlorine. The possible mechanisms of biocidal action of chlorine is based on the basic principle that $\mathrm{HOCl}$ easily penetrates through the cell wall of the organism, and being an oxidizing agent, oxidizes the enzyme groups responsible for the growth of the organisms and bring about death in the case of micro organisms. However, in the case of macro-organisms in addition to cellular damages, the process of death is also accelerated by the reduction in growth, decrease in filtration rate, decrease in food availability, as well as pathological effects. $\mathrm{HOCl}$ being a weak acid it undergoes partial dissociation to give $\mathrm{H}^{+}$and $\mathrm{OCl}^{-}$.

$$
\mathrm{HOCl}<=>\mathrm{H}^{+}+\mathrm{OCl}^{-}
$$

This equilibrium is $\mathrm{pH}$ dependent and so also the fraction of total chlorine present. It is known that $\mathrm{HOCl}$ is a better biocide than $\mathrm{OCl}^{-}$due to its (a) electrical neutrality, (b) structural similarity with that of water facilitating easy penetration through cell wall and (c) the process of penetration being more of a physical process than a chemical one requiring less amount of energy. Thus, from the point of view of efficiency of treatment it is beneficial to have more amount of undissociated $\mathrm{HOCl}$ in the cooling water in order to exploit the total potential of chlorine as a biocide. If cooling water happens to be seawater, the $\mathrm{pH}$ of which is about 8 , when chlorine is added to seawater a little more than $80 \%$ of the total chlorine will be present as $\mathrm{OCl}^{-}$(Fig. 14a). However, the presence of about $65 \mathrm{mg}$ of bromide per $\mathrm{kg}$ of seawater compensates this disadvantage. $\mathrm{HOCl}$ gets converted to $\mathrm{HOBr}$ as follows (Venkateswarlu, 1990):

$$
\begin{gathered}
\mathrm{HOCl}+\mathrm{Br}^{---->} \mathrm{HOBr}+\mathrm{Cl}^{-} \\
\mathrm{OCl}^{-}+\mathrm{Br}^{----}>\mathrm{OBr}^{-}+\mathrm{Cl}^{-}
\end{gathered}
$$

A major portion (75 \%) of $\mathrm{HOBr}$ remains undissociated at seawater $\mathrm{pH}$ (Fig.14b). Thus, in seawater it is the bromine species which plays a significant role as a biocide after the addition of chlorine. Moreover, the conversion of $\mathrm{HOCl}$ to $\mathrm{HOBr}$ in seawater is $\mathrm{pH}$ dependent as evident below (Table 6). It is important to have knowledge on $\mathrm{HOBr}$ conversion kinetics (Goodman, 1987), which would facilitate the location of chlorine injection point in order to achive $100 \% \mathrm{HOBr}$ conversion. Molecular chlorine, hypochlorous acid, hypobromous acid, hypobromite and hypochlorite ions are called free chlorine (oxidant) (White, 1972). In stead of free or combined chlorine or bromine it is appropriate to use the term free residual oxidant, combined residual oxidant and total residual oxidant due to the existence of one or more species at a given time. However, for convenience sake the former is used in this chapter. Almost all natural waters contain ammonia or amines which combine with chlorine to give chloramines and bromamines and they are called combined chlorine (equation 5-7). Although, they have biocidal action however, the magnitude is significantly lower than that of free chlorine (White, 1972).

$$
\begin{gathered}
\mathrm{NH}_{3}+\mathrm{HOCl}=\mathrm{NH}_{2} \mathrm{Cl} \text { (monochloramine) }+\mathrm{H}_{2} \mathrm{O} \\
\mathrm{NH}_{2} \mathrm{Cl}+\mathrm{HOCl}=\mathrm{NHCl}_{2} \text { (dichloramine) }+\mathrm{H}_{2} \mathrm{O} \\
\mathrm{NHCL} 2+\mathrm{HOCL}=\mathrm{NCl} \text { (trichloramine) }+\mathrm{H} 2 \mathrm{O}
\end{gathered}
$$




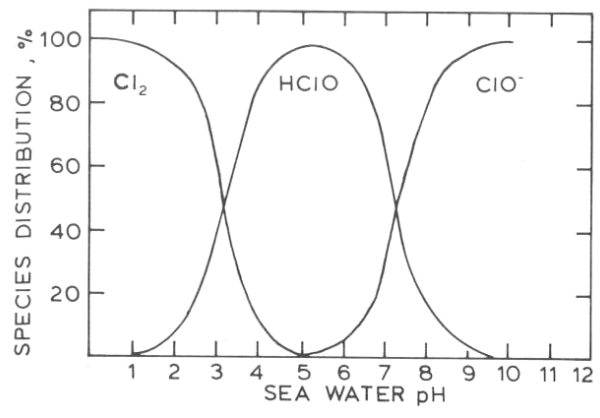

(a)

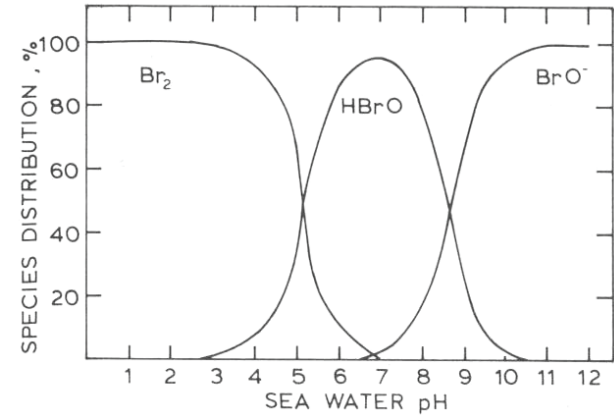

(b)

Fig. 14. Distribution of chlorine (a) and bromine (b) species with $\mathrm{pH}$

The combination of both free chlorine and combined chlorine is called total residual chlorine or total residual oxidants. In this regard, it is worthwhile to maintain here that biofouling organisms settled inside a cooling system could affect the efficiency of chlorination as they produce ammonia as their excretal product. A variation of ammonia production with different size of mussel at two different temperatures is given in Fig. 15a. The amount of mono, di- and tri- chloramine present in the water during chlorination depends on $\mathrm{pH}$ and $\mathrm{NH}_{3}$ content of cooling waters. The effectiveness of various chlorine species with regard to their biocidal action to organisms follows the following order, free chlorine $>$ hypochlorite ion $>$ chloramines

\begin{tabular}{lc}
\hline $\mathrm{pH}$ & Time, s \\
6 & 2 \\
7 & 3 \\
8 & 10 \\
9 & 80 \\
\hline
\end{tabular}

Table 6. Kinetics of HOBr conversion with pH (Goodman, 1978)

In water containing ammonia nitrogen, a typical reaction occurs called break-point reaction. The formation of mono, di- and trichloramine depends on chlorine to $\mathrm{NH}_{3}$ ratio. If $\mathrm{Cl}_{2}$ to $\mathrm{NH}_{3}$ ratio (molar) $<1$, formation of mono- chloramine takes place, when this ratio exceeds 1 , dichloramine is formed and finally when it exceeds 1.5 trichloramine is formed. However, mono-, di- and trichloramine using a reaction give rise to disappearance of chlorine by the following equation.

$$
\mathrm{NH}_{2} \mathrm{Cl}+\mathrm{NHCl}_{2}+\mathrm{HOCl}=\mathrm{N}_{2} \mathrm{O}+4 \mathrm{H}^{+}+4 \mathrm{Cl}^{-}
$$

The striking feature of this reaction is that even when initial chlorine concentration is increased, the total residual chlorine concentration is decreased due to the above reaction. The point where total residual chlorine reaches a minimum in the curve is called break-point. A typical break point curve is given in Fig. 15b. After this point most of the residuals are free residuals and it increased with increased chlorine dose. This phenomenon is very important in the context of disinfection of drinking water and also in the case of shock chlorination. That is a chlorine dose, beyond break point chlorination is advisable to achieve a very high disinfection factor. 


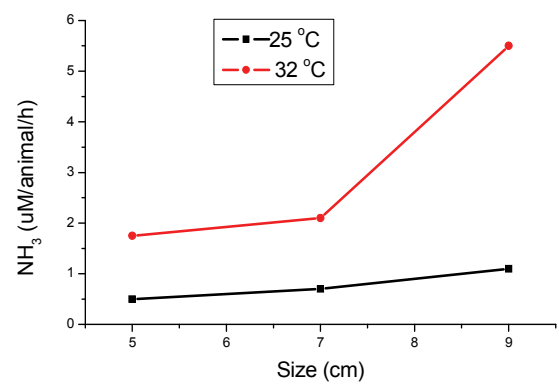

(a)

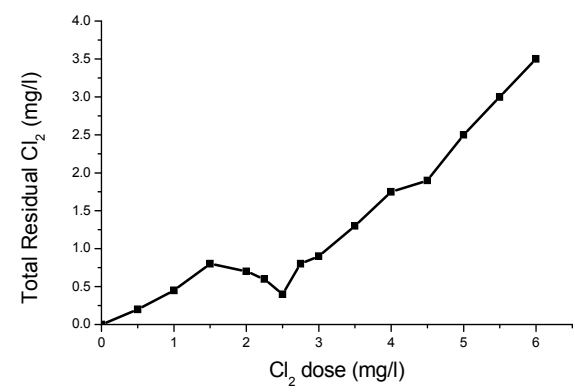

(b)

Fig. 15. Variations of ammonia production with different sizes of mussels at two different temperatures (a) and a typical break point curve (b)

To eliminate already established fouling community, shock chlorination is used. Moreover, sometimes during very low flow or no flow situation, the cooling water is soaked with chlorine for a specified time to kill the settled fouling community and the process is called soak chlorination.

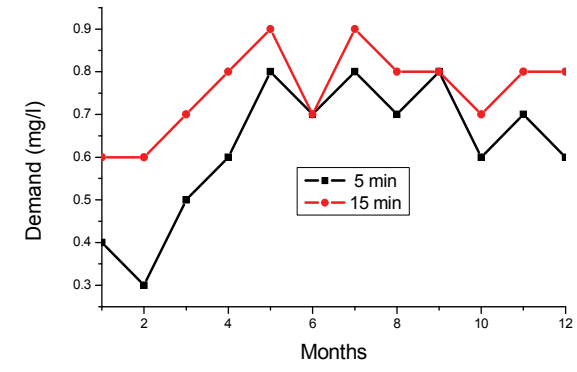

(a)

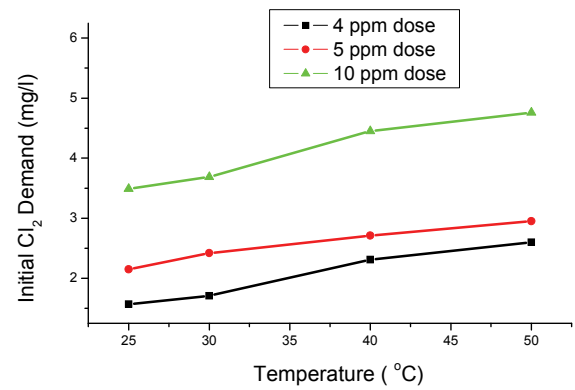

(b)

Fig. 16. Monthly variations of chlorine demand in the coastal water of Kalpakkam (a) and interrelation between temperature and chlorine demand

Chlorine can also disappear through reactions with reducing inorganic compounds such as S-, $\mathrm{Fe}^{++}$and $\mathrm{NO}_{2}^{-}$and gets itself reduced to chloride. It also can react with organic materials by substitution forming chloro-organic compounds and also can oxidize them, converting them to another higher oxidation level compound or decomposed into $\mathrm{CO}_{2}$ and $\mathrm{H}_{2} \mathrm{O}$. These reactions are called chlorine demand reactions and this amount of chlorine is not available for biocidal action (White, 1972). This chlorine demand among others mainly depends on time of contact, temperature, chlorine dose, and more importantly the quality of the cooling water which varies from month to month and even day-to-day depending on the location. It is essential to have a 
full knowledge of the chlorine demand of cooling water for a period of at least two years, so as to avoid under chlorination as well as over chlorination (Venkateswarlu, 1990).

Seawater samples from PFBR site were collected and were dosed with $1 \mathrm{mg} \mathrm{l}^{-1}$ and $10 \mathrm{mg} \mathrm{l}^{-1}$ standard chlorine solution (prepared from bleaching powder). The iodometric method as described by White (1972) was employed for the determination of residual chlorine after different contact times $(5,30$, minutes). Similarly, for $10 \mathrm{ppm}$ chlorine dose residual chlorine was measured after 5 \& 15 minutes. A typical example of monthly variations of chlorine demand in cooling water is given in Fig. 16a. It clearly depicts that to maintain a particular residual at the outlet of the cooling water throughout the year; a variable dose is essential rather than a constant one which is generally adopted. Moreover, the dependence of temperature on chlorine demand is explained in Fig. 16b.

Chlorine demand at low doses: Chlorine demand results showed that the demand varied widely from a minimum 0.3 to a maximum $0.9 \mathrm{mg} \mathrm{l}^{-1}$. The variation clearly pointed out that different amount of chlorine has to be added to the cooling water during different months to maintain a particular residual for effective biofouling control and minimal damage to the environment. The results also showed that the demand increased with increasing time (Fig. 16a) indicating that during relatively longer residence time (shut down period) appropriate quantity of $\mathrm{Cl}_{2}$ has to be added to maintain the residual taking long duration and low flow rate into account. The duration of demand study is decided based on the residence time, the cooling water spends inside the cooling water system.

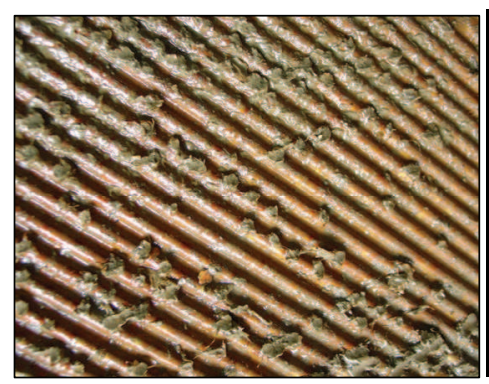

(a)

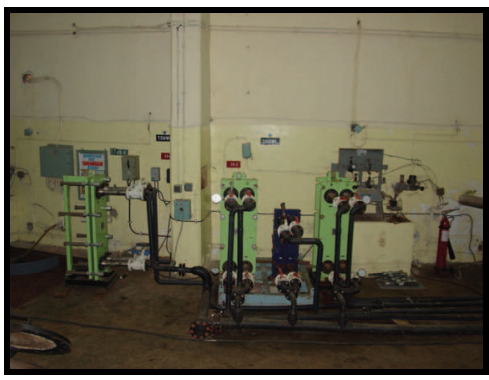

(b)

Fig. 17. A view of a plate heat exchanger (a) \& the plate heat exchanger facility at MAPS (b)

Chlorine Demand at 10 ppm doses: The Process Seawater Heat Exchanger (PSWHX) of PFBR is going to be plate type instead of tube type, which is being used at MAPS. Unlike tube type, which has got a gap of about $25 \mathrm{~mm}$ diameter, the gap between any two plates in plate type of heat exchanger is very small ( 3 to $4 \mathrm{~mm}$ ). A pictorial view of Titanium plate heat exchanger \& biogrowth on it is shown in Fig. 17. Considering the bio-growth potential of seawater at Kalpakkam, there is every likelihood that PSWHX would get into severe biofouling unless proper remedial measures are taken. In view of this, a new regime called targeted chlorination (Chow et al., 1987) with relatively high dose (10-20 ppm) and short duration (10-20 min) has been suggested to overcome this problem. In this context, the chlorine consumption in the side reaction at $10 \mathrm{ppm}$ dose and short duration ( 5 and 15 minutes) has been carried out. The result (Fig. 18) showed that 10 to $25 \%$ chlorine is consumed during this short period leaving the remaining for bio-fouling control in the plate HX. To precisely and accurately decide the dose 
and duration, a dynamic loop has been set up with facility to carry out experiments at different flow rates for biofouling control in PSWHX.

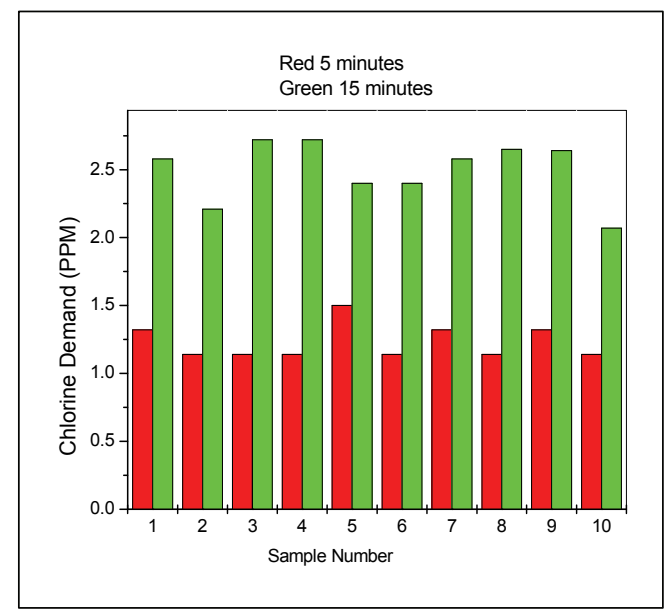

Fig. 18. Chlorine demand for $10 \mathrm{ppm}$ dose for 5 and 15 minutes contact time

\subsubsection{Macrofouling control}

To overcome the problem of macro fouling, long term low level continuous chlorination is usually used and such a practice is also effective in the control of condenser slime. This was originally started at Carmarthen power station U.K. The dose employed is insufficient to kill mussels but sufficient to create an environment to deter them from settling in the cooling water system and to cause them to move out (and hence the term exomotive chlorination) (Beauchamp, 1966; Garey, 1980; and Kasper and Taft, 1984). Exomotive chlorination is found to be economical and relatively harmless to important nontarget commercial organisms. Some of the chlorination schedules being practiced in operating power stations are given in Table 7. Owing to the safety problem associated with the transport and storage of liquid chlorine, there have been attempts to look for alternative sources of chlorine. Other sources such as liquid hypochlorite solution and chlorine from electrolysis of brine of seawater have been tried in UK, USA, France and Italy (Whitehouse et al., 1985). Transport and storage of hypochlorite solution as well as some safety risks have become stumbling blocks for its use. Though safety problems are eliminated in electrochlorination, other drawbacks such as considerable financial investment, (capital cost $50 \%$ and production cost $20 \%$ higher than liquid chlorine), as well as difficulties in maintenance of particular residual levels (due to varying seasonal chlorine demand) remain. There are also safety problems associated with the production of large volumes of hydrogen gas and poor efficiency of the electrolysis process at lower temperature which made electrochlorination not very attractive. A recent successful use of a combination of copper and chlorine has been reported by both CEGB and EPRI. Results of both showed that the chlorine and copper system was at least 6 times as effective as chlorine alone against macrofouling and three times as effective against microfoulants (Strauss, 1989). Three major common problems associated with the use of chlorine irrespective of its source are: (i) safety associated with transport and storage (ii) long term potential threat to marine life and (iii) carcinogenicity of chloroorganics which are produced 
during chlorination (Brungs, 1977; Fiessinger et al., 1985; Saravanane et al., 1998, Satpathy et al., 2008). Whitehouse (1975) gives a detailed account of the effect of chlorine on aquatic life.

\begin{tabular}{|c|c|c|}
\hline Location & Clorination Scheduales & Sources \\
\hline $\begin{array}{l}\text { Kansai } \begin{array}{l}\text { Electric } \\
\text { Company, Japan }\end{array} \\
\text { Power }\end{array}$ & $0.0-0.2 \mathrm{ppm}$ residual continuous. & Kawable et al.,1987 \\
\hline $\begin{array}{l}\text { Tanagawa Power Station, } \\
\text { Japan }\end{array}$ & $0.5 \mathrm{ppm}$ residual 4 times per day for $1 \mathrm{hr}$. & Kawable et al.,1987 \\
\hline $\begin{array}{lll}\text { Carmarthen } & \text { Bay } & \text { Power } \\
\text { Station, UK. } & & \\
\end{array}$ & 0.02-0.05 ppm residual continuous. & James,1967 \\
\hline France & 1 ppm dose & Whitehouse et al .1985 \\
\hline Maps, India & $0.5 \mathrm{ppm}$ residual continuous & Namboodiri, 1987 \\
\hline Le Havre, Italy & 0.5 ppm dose continuous. & Whitehouse, et al., 1995 \\
\hline Coastal Station in the UK & continuous low level chlorination & Whitehouse, 1978 \\
\hline Netherlands. & $\begin{array}{l}0.2 \text { ppm free available halogen just before } \\
\text { condenser, once in } 4 \mathrm{hrs} \text {. for } 4 \mathrm{hrs}\end{array}$ & Jenner, 1983 \\
\hline
\end{tabular}

Table 7. Chlorination practice being followed at different operating power plants.

In 1982 EPA guideline stipulated that chlorine discharge from power plants should not be more than $0.2 \mathrm{ppm}$ for 2 hours as total residual chlorine or total residual oxidant (Rittenhouse, 1987). Recent EPA recommendation sets acceptable total chlorine limits at $0.05 \mathrm{mg} / 1$ for a period of 30 minitues in any 24 hour period. The environmental pollution prevention agreement in Japan stipulates that residual chlorine levels at the water outlets must not be detectable (Kawabe et al., 1986). Sometimes an abundance of ammonia and a high $\mathrm{pH}(>8)$ make biofouling control with chlorine very difficult (Chiesa and Geary, 1985). At slightly higher doses chlorine also accelerates corrosion of $\mathrm{Cu}$ and mild steel particularly at higher velocity (Stone et al., 1987, Reiber et al., 1987 and Pisigan and Singley, 1987).
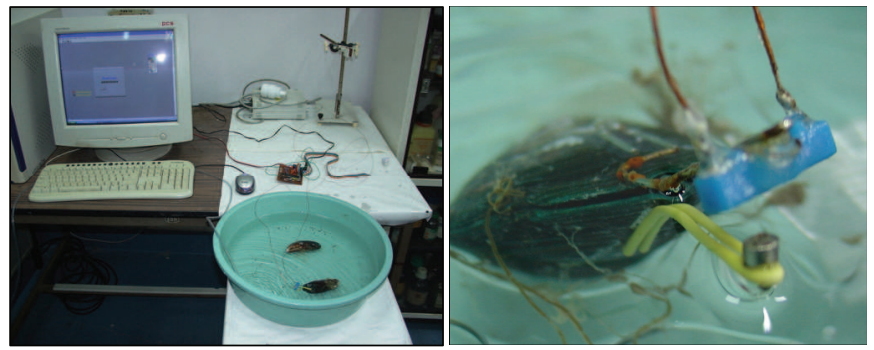

Fig. 19. Mussel valve monitoring experimental setup and a mussel with sensors attached

Although low level continuous chlorination appears to be a panacea for controlling bivalves, pulsed biocide dosing, a new concept has been proposed as a more effective tool than the former. Bivalves, as soon as it senses biocide, closes its shells and so also filtration, a process solely responsible for feeding and respiration of these organisms. They tend to open their shells after a certain period of time and immediately close if the biocide presence in water continues. Thus, instead of chlorinating continuously, chlorine can be injected at intervals coinciding with the closing and opening intervals of the mussel shell to take advantage of this behaviour. Knowledge on this closing and reopening of mussels will be useful for deciding the optimum frequency of pulsed biocide dosing so that operational cost and environmental damage due to biocide is minimised. However, this interval is not generic and information on the same is not 
available in literature. A micro-sensor based magnetic reed relay (Fig. 19) has been designed and developed to sense the opening and closing of the mussels. Once standardised, it could be implemented to reduce operational cost and save the environment.

\subsubsection{Microfouling/ Slime control}

Microbiological fouling in cooling water is caused by biofilms. The biofilms are loose configurations of many different kinds of bacteria; a slimy substance they produce called exopolysaccaride (EPS) holds it all together. Biofilms, which cause dental cavities and diseases such as cystic fibrosis, are ubiquitous in virtually all kinds of water piping. In industrial processes, biofilms can cause corrosion and seriously affect flow, pressure drop, and the efficiency of heat transfer from metal surfaces. In the case of slime control, chlorine is used on the basis of two principles, (i) let the slime accumulate for a predetermined length of time, then start chlorination for a period during which the adhesive slime forming organisms will be killed and then washed away by the velocity of water, (ii) the interval between successive treatment should not be long enough for the accumulated slime to attain a thickness, which will interfere with heat transfer. A variation in biofilm thickness with time in the coastal water of Kalpakkam is shown in Fig. 20a. Such a practice involving operation of chlorination at pre-determined intervals for a specified duration (usually 30 minutes) is known as intermittent chlorination. Frequency is determined by the above two factors. Duration is decided by the turnover time for the cooling system. Magnitude and type of residual chlorine (free or total) is decided by the type of slime. The point of chlorine application should be located as close as possible to the inlet of the heat exchanger to take care of the free chlorine component of the residual. It is important that the kinetics of speciation of residual chlorine is studied for cooling water so as to decide the location of injection. Fig. 20b shows the variation in residual chlorine speciation with time.

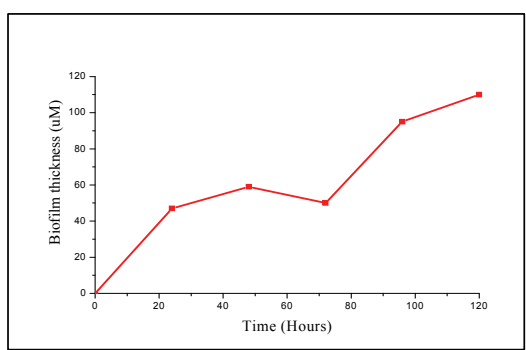

(a)

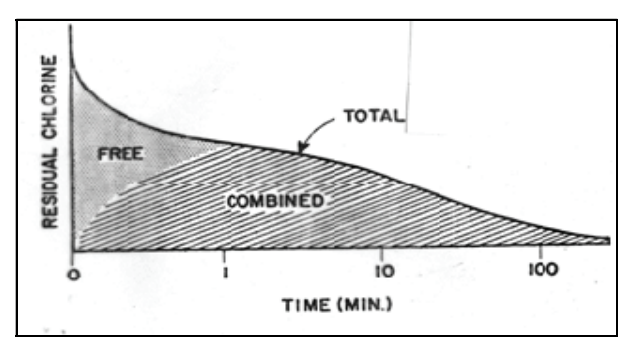

(b)

Fig. 20. Rate of biofilm formation in the coastal waters of Kalpakkam and speciation of residual chlorine with time

\section{Conclusion}

Chlorination for biofouling control in cooling water system was initiated way back in 1924. Even after eight and half decades, chlorine remains the most widely used biocide for biofouling control barring a few cases wherein other propriety chemicals have crept in. It appears that under the present known knowledge and economical viability it will still continue to rule the roost. Thus, its chemistry for cooling water is studied well before it is applied to cooling water. In the present study, seasonal variation in chlorine demand was observed. Therefore, it is essential that the 
chlorine demand values are quantified precisely and accurately so that under and over chlorination is avoided. Moreover, the operational cost of chlorination is optimized so that with minimum $\mathrm{Cl}_{2}$, maximum biocidal efficiency is achieved. Although, other methods have been proved to control biofouling in laboratory scale, they have not been able to replace chlorine in plant scale.

Life supporting activities such as respiration, feeding, metabolism and excretion of the biofoulers settled inside the cooling water system could considerably alter the cooling water quality both chemically and biologically affecting the control regime adversely. Results of settlement pattern of biofouling organisms reveal that, before attempting to finalize the control regime (mode, frequency, duration etc), a thorough knowledge on the type of organisms, their breeding pattern, climax species etc is essential.

\section{References}

Anil, A. C. \& Wagh, A. B. (1988). Aspects of biofouling community development in the Zuary estuary, Goa, India. In: Marine biodeterioration: advanced technique applicable to the Indian Ocean, M. P. Thompson, R. Sarojini, \& R. Nagabhushanam, (Eds.), 529-537, Oxford \& IBH publishing (P) Ltd., New Delhi, India

Anil, A. C.; Chiba, K. \& Okamoto, K. (1990). Macrofouling community structure and ecology of barnacles in Hamana Bay (Japan), Biofouling, 2, 137-150

Babu, M. T. (1992). Equator-ward western boundary current in the Bay of Bengal during November-December 1983, Physical Processes in the Indian Seas (Proceedings of First Convention, ISPSO), pp. 57-62

Beauchamp, R. S. A. (1966). Low level chlorination for the control of marine fouling. C.E.G.B. Report no. RD/L/M 147, 1-7

Bhosle, N. B.; Nandkumar, K. \& Wagh, A. B. (1989). Influence of pariculate matter on microfouling biomass in the Arabian Sea, Biofouling, 2, 65-74

Brankevich, G.; Bastida, R. \& Lemmi, C. (1988). A comparative study of biofouling settlements in different sections of Necochea power plant (Quequen port, Argentina), Biofouling, 1, 113-135

Brungs, W. A. (1977). General consideration concerning to the toxicity to aquatic life of chlorinated condenser effluent, In: Biofouling control procedures; technology and ecological effects, L.D. Jensen, (Ed.), 109-113, Marcel Dekker, New York

Brungs, W. H. (1973). Literature review of the effects of residual chlorine on aquatic life, Journal of Water Pollution, 45, 2180-2193

Carpenter, R. C. (1990). Competition among marine macroalgae: a physiological perspective, Journal of Phycology, 26, 6-12

Chadwick, W. L.; Clark, F. S. \& Fox, D. L. (1950). Thermal control of marine fouling at the Redondo stem station of southern California Edison Company, Trans American Society of Mechanical Engineering, 72, 127-131

Chalmer, P. N. (1982). Settlement patterns of species in a marine fouling community and some mechanisms of succession, Journal of Experimental Marine Biology and Ecology, 58, 73-86 
Chen, J. C.; Chen, C. T. \& Cheng, S. Y. (1994). Nitrogen excretion and changes of haemocynine, protein and free amino acid levels in the haemolymph of Penaeus monodon exposed to different concentrations of ambient ammonia- $\mathrm{N}$ at different salinity levels, Marine Ecology Progress Series, 110, 85-94

Chiesa, R. \& Geary, D. (1985). Evaluation of alternative chemicals for power plant condenser biofouling control, Proceedings of $46^{\text {th }}$ Annual meeting, International Water Conference, ICW 85-42, pp. 1-10, Pittsburgh

Chow, W. (1987). Targeted chlorination schedules and corrosion evaluations, American Power Conference, Chicago

Clarke, A.; Thomas, E. P. \& Whitehouse, M. J. (1994). Nitrogen excretion in the Antartic limpet Nacella concinna (Strebel, 1908), Journal of Molluscan Studies, 60, 141-147

Collins, T. M. (1964). A method for designing seawater culverts using fluid shear for the prevention of marine fouling. CERL Report no. RD/1/N93/64, 1-5

Corpe, W. A. (1984). The microfouling problem and the future of the ocean thermal conversion program, MTS Journal, 13, 21-25

Coughlan, J. and Whitehouse, J. (1977). Aspects of chlorine utilization in the UK, Chesapeake Science, 18, 102-111

Crisp, D. J. (1961). Territorial behavior in barnacle settlement, Journal of Experimental Biology, 38, 429-446

Dahlem, C.; Moran, P. J. \& Grant, T. R. (1984). Larval settlement of marine sessile invertebrates on surfaces of different colour and position, Ocean Science and Engineering, 9, 225-236

Daling, P. M. \& Johnson, K. I. (1985). Current status of biofouling surveillance and control Techniques, Bivalve fouling of nuclear power plant service water systems, NUREG/CR-4070, PNL-5300 U.S. NRC, Washington, D.C.

Darby, J. B. Jr. (1984). Ocean thermal conversion material issues, Journal of Materials for Energy Systems, 6, 130-137

De Souza, S. N.; Naqvi, S. W. A. \& Reddy, C. V. G. (1981). Distribution of nutrients in the western Bay of Bengal, Indian Journal of Marine Sciences, 10, 327-331

Drake, R. C. (1977). Increasing heat exchanger efficiency through continous mechanical tube maintenance, In: Biofouling control procedures; technology and ecological effects, L.D. Jensen, (Ed.), 43-53, Marcel Dekker, New York

Duke Power Co. 1981, Letter from W.O. Parker to J.P. O'Reilly transmitting Duke Power company's response to the NRC IE Bulletin 81-03 for the McGuire Nuclear Plants

Fiessinger, F.; Rook J. J. and Duguet, J. P. (1985). Alternative methods for chlorination, The Science of Total Environment, 47, 299-315

Fisher, E. C. (1984). Technology for control of marine biofouling - a review. In: Marine biodeterioration- an interdisciplinary study, J. D. Costlow, (Ed.), 261-290, Naval Institute press, Annapolis Maryland

Garey, J. F. (1980). Selective alternatives to conventional chlorination, EPRI Report no EA-1588, 1-94

Gleason, H. A. (1922). On the relation between species and area, Ecology, 3, 156-162

Godwin, W. (1980). Ecology of the coastal fauna around Madras Atomic Power Plant, Ph. D. Thesis, University of Madras, Madras, India 
Goodman, P. D. (1987). Effect of chlorination on materials for sea water cooling system: A review of chemical reactions, British Corrosion Journal, 22, 65-62

Haried, J. A. (1982). Evaluation of events involving service water systems in nuclear power plants, NUREG/CR-2797,ORNL/NSIC-207, U.S. NRC, Washington, D.C.

Haugen, V. E.; Vinayachandran, P. N. and Yamagata, T. (2003). Comment on Indian Ocean: Validation of the Miami Isopycnic coordinate ocean model and ENSO events during 1958-1998, Journal of Geophysical Research, 108, 3179, doi: 10.1029/2002JC001624

Henager, C. H.; Daling, P. M. \& Jhonson, K. I. (1985). Factors that may intensify the safety consequences of biofouling, Bivalve fouling of nuclear power plant service water system, NUREG/CR 4070, U.S. NRC, Washington, Washington, D.C.

Holems, N. (1967). Mussel settlement in the cooling water intake screens at the Poole power station, CERL Report No. RD/1/N/137/67, Leatherhead, Surrey

Imbro, E. V. (1982). Engineering evaluation of the salt service water system flow blockage at the Pilgrim nuclear power station by Blue Mussels (Mytilus edulis), Office for analysis and evaluation of operational data, U.S. NRC, Washington, D.C.

Imbro, E.V. \& Gianelli, J.M. (1982). Report on service water system flow Blockages by Bivalvine Mollusks at Arkansas Nuclear one and Brunswick, Office for analysis and evaluation of operational data, U.S. NRC, Washington, D.C.

Iwaki, T. \& Hattori, H. (1987). First maturity and initial growth of some common species of barnacles in Japan, Bull. Fac. Fish. Mie. Univ., 14, 11-19

Iwaki, T.; Hibino, K. \& Kawahara, T. (1977). Seasonal changes in the initial development of fouling communities in Matoya Bay, This. Bull., 4, 11-29

James, W. G. (1967). Mussel fouling and use of exomotive chlorination, Chemical Industries, 994-996

Kajihara, T.; Hirano, R. \& Chiba, K. (1976). Marine fouling animals in the bay of Hamana - kobe, Japan, The Veliger, 18, 361-366

Karande, A. A.; Gaonkar, S. N. \& Swami, B. S. (1986). Marine biofouling and its assessment in Indian waters, Proceedings of 3rd Indian Conference on Ocean Engineering, 2, pp. 21-35, IIT, Powai, Bombay, India

Karande, A.; Srinivasan, A. K. \& Viswanathan, R. (1983). Marine biofouling in sea water tunnel. NCML/ BARC Report, Bombay, India

Kasper, J. R. \& Taft, E. P. (1984). Macrofouling control at steam electric generating station- A case for continuous low level chlorination, Proceedings of American Power Conference, pp. 960-964, Chicago

Kawabe, A. (1986). Effect of flow dynamics on attachment of marine organisms for copper and copper alloys seawater pipes, Communication, 53, 422-423

Khandeparker, D. C.; Anil, A. C. \& Venkat, K. (1995). Larvae of fouling organisms and macrofouling at New Mangalore port, west coast of India, Indian Journal of Marine Sciences, 24, 37- 40

La Fond, E. C. (1957). Oceanographic studies in the Bay of Bengal, Proceedings of Indian Academy of Sciences, 46, 1-46

Little, B. J. \& De Palma, J. R. (1988). Marine Biofouling, In: Materials for marine systems and structures, D.F. Hanson, (Ed.), 90-121, Trans Tech Publications, Switzerland 
Masilamani, J. G.; Azariah, J.; Nandakumar, K.; Jesudoss, K.; Satpathy, K. K. \& Nair, K. V. K. (2001). Excretory products of green muscle Perna viridis and their implication on power plant operation, Turkish journal of Zoology, 25, 117-125

Masilamani, J. G.; Jesudoss, K. S.; Nandakumar, K.; Satpathy, K. K.; Nair, K. V. K. \& Azariah, J. (2000). Jelly fish ingress: A threat to smooth operation of coastal power plants, Current Science, 79(5), 567-569

Masilamani, J.G., Jesudoss, K.S., Nandakumar, K., Satpathy, K.K., Nair, K.V.K. \& Azariah, J. (1997). Physiological response of the green mussel Perna viridis in relation to size and salinity. Proceedings of Indian Academy of Sciences, B63 (4), p305-314.

Masilamani, J.G., Nandakumar, K., Satpathy, K.K., Jesudoss, K.S., Nair K.V.K.\& Azariah. J. (2002). Lethal and sublethal responses of chlorination on green mussel Perna viridis in the context of biofouling control in power plant cooling system. Marine Environmental Research, 53(1), p65-76.

Masilamani, J.G., Satpathy, K.K., Jesudoss, K.S., Nandakumar, K., Nair K.V.K. \& Azariah. J. (2002). Influence of temperature on the physiological responses of the bivalve; Brachidontes striatulus. Marine Environmental Research. 53(1), p51-64.

Miller, R. H. (1974). A note on the breeding season of three ascidians on coral reefs at Galeta in the Caribean Sea, Marine Biology, 28, 127-129.

Murugan, A. \& Ramasamy, M. S. (2003). Biofouling deterrent activity of the natural product from ascidian, Distaplia nathensis, Indian journal of marine sciences, 32(2), 162-164

Myint, U. M. \& Tyler, P. A. (1982). Effects of temperature, nutritive and metal stressors on the reproductive biology of Mytilus edulis, Marine Biology, 67, 209-223

Nair, K. V. K. (1985). Impact of nuclear power station on the hydrographical characteristics of Kalpakkam coastal waters, Proceedings of Symposium on sea water quality demand, pp. 13.1-13.10, NCML, Bombay

Nair, K. V. K. (1987). Biofouling porblems in cooling conduits of power stations. In: Advances in aquatic biology $\mathcal{E}$ fisheries: Symposium to facilitate Dr. N.B. Nair, 257262, Kerala University, Trivandrum

Nair, K. V. K.; Murugan, P. \& Eswaran, M. S. (1988). Macrofoulants in Kalpakkam coastal waters, east coast of India, Indian Journal of Marine Sciences, 17, 341-343

Nair, K. V. K.; Satpathy, K. K. \& Venugopalan, V. P. (1997). Bio-fouling control: Current methods \& new approaches with emphasis on power plant cooling water system. In: Fouling organism of the Indian oceans, biology and control technology, R. Nagbhusanam, (Ed.), 158-188, Oxford \& IBH Publishing Company, New Delhi, India

Nair, K.V.K.; Ganapathy, S. (1983). Baseline ecology of Edayur-Sadras estuarine system at Kalpakkam. I: General hydrographic and chemical feature, Mahasagar, 16, 143-151

Nair, N. U. \& Nair, N. B. (1987). Marine biofouling dynamics in and around the Cochin harbour. Proceedings of National seminar on estuarine management, Trivandrum, India 
Neitzel, D.A.; Johnson, K.I.; Page, T.L.; Young, J.S. \& Daling, P.M. (1984). Correlation of bivalve biological characteristics and service water system design, In: Bivalve Fouling of Nuclear Power Plant Service Water Systems, Vol. 1, 1-119 U.S. Nuclear Regulatory Commission, Washington

Nelson, W.G. (1981.) Inhibition of barnacle settlement by Ekofisk crude oil, Marine Ecology Progress Series, 5, 41-43

Newell, R. I. E.; Hilbish, T. J.; Koehn, R. K. \& Newell, C. J. (1982). Temporal variation in the reproductive cycle of Mytilus edulis L. (Bivalvia, Mytilidae) from localities in the east coast of the United States, Biology Bulletin, 162, 299-310

Nuclear Regulatory commission. (1984). Power reactor events, NUREG/BR-0051, Vol.5, No.4. U.S. NRC, Washington, D.C.

Paul, M. D. (1942). Studies on the growth and breeding of certain sedentary organisms in the madras harbour, Proceedings of Indian Academy of Sciences, 150, 1-42

Pielou, P. P. (1966). The measurement of diversity in different types of biological collections, Journal of Theoritical Biology, 13, 131-144

Pieters, H.; Kluytmans, J. H.; Zandee, D. I. \& Cadee, G. C. (1980). Tissue composition and reproduction of Mytilu edulis in relation to food availability, Netherlands Journal of Sea Research, 14, 349-361

Pisigan, R. A. Jr. and Singley, J. E. (1987). Influence of buffer capacity, chlorine residual and flow rate on corrosion of mild steel and copper, Journal of American Water Works Association, February, 62-70

Portland General Electric Co. (1981). Letter from B.D. Witners to R.H. Engelken transmitting Trojan Nuclear Plant's Response to IE Bulletin 81-03

Price, A. H.; Hess, C. T. \& Smith, C. W. (1975). Observations of Crassostria virginica cultured in the heated effluent and discharged radionuclides of a power reactor, Proceedings of National shellfish Association, 66, 54-68

Rains, J. H., Foley, W. J., \& Hennik, A. (1984). Flow blockage of cooling water to safety system components by Corbicula sp. (Asiatic clam) and Mytilus sp. (mussel), USNRC, Report No. NUREG/CR 3054, Washington, D.C.

Rajagopal, S.; Nair, K. V. K.; Velde, G. V. D. \& Jenner, H. A. (1997). Seasonal settlement and succession of fouling communities in Kalpakkam, east coast of India, Netherlands Journal of Aquatic Ecology, 30, 1-17

Rajagopal, S.; Sashikumar, N.; Azsariah, J. \& Nair, K. V. K. (1991). Some observations on biofouling in the cooling water conduits of a coastal power plant, Biofouling, 3, 311-324

Ramaraju, V. S.; Sarma, V. V.; Rao, P. B. \& Rao, V. S. (1992). Water masses of Visakhapatnam shelf, In: Physical processes in Indian seas (Proceedings of First Convention, ISPSO, 1992), pp. 75-78

Rao, S. K. \& Balaji, M. (1988). Biological fouling at Kakinada, Godavary estuary, Oxford IBH publisher, New Delhi, India

Raymont, J. E. G. (1983). Plankton and productivity in the Oceans: Vol. II Zooplankton, Pergamon press

Reiber, S. H.; Ferguson, J. F. \& Benjamin, M. M. (1987). Corrosion monitoring and control in the Pacific northwest, Journal of American Water Works Association, 79, $71-74$ 
Relini, G.; Bianchi, C. N. \& Pisano, E. (1980). Macrofouling in the conduits of a middle Tyrrhenian power station, Proceedings of 5th International Congress on Marine Corrosion and Fouling, pp. 279-292, Madrid

Renganathan, T. K. (1990). Systematics and ecology of Indian ascidians, In: Marine Biofouling and power plants, K. V. K. Nair \& V. P. Venugopalan, (Eds.), 263-271, BARC, Bombay, India

Richmond, M. D. \& Seed, R. (1991). A review of marine macrofouling communities with special reference to animal fouling, Biofouling, 3, 151-168

Rippon, J. E. (1979). UK Biofouling Control Practices, EPRI symposium on biofouling in condensers, 1-36, Atlanta, USA

Rittenhouse, R. C. (1987). Biofouling/oil/additives: work ahead, Power Engineering, February, 8

S. M. Stoller Corp. (1977). DG heat exchangers clogged with mussels- inadequate chlorination schedule, In: Nuclear power experience, Vol. PWR-2, Section VIII, subsection B, 40

S. M. Stoller Corp. (1978). Service pump strainers damaged by Ice- excessive silt build up, In: Nuclear power experience, Vol PWR-2, section VIII, Subsection B, 50

S. M. Stoller Corp. (1983). SW filter drive motor shaft key sheared, pump seized Excessive debris, In: Nuclear power experience, Vol PWR-2, section VIII, Subsection B, 130

Sahu, G.; Satpathy, K. K.; Laxmi, S.; Prasad, M. V. R.; Murthy, P. S. \& Venkatesan, R. (2006). Spatial and temporal variation in phytoplankton community in the coastal waters of Kalpakkam and their impact on fouling, Proceedings of Recent Advances in Marine Antifouling Technology, pp. 538-552, Chennai, India

Saravanane, N., Satpathy, K.K., Nair, K.V.K. \& Durairaj, G. (1998). Preliminary observations on the recovery of tropical phytoplankton after entrainment. Thermal Biology, 23(2), p91-97.

Saravanane, N.; Nandakumar, K.; Durairaj, G. \& Nair, K. V. K. (2000). Plankton as indicators of coastal water bodies during southwest to northeast monsoon transition at Kalpakkam, Current Science, 78, 173-176

Saravanane, N.; Satpathy, K.K.; Nair, K.V.K. \& Durairaj. G. (1998). Studies on the recovery of entrained phytoplankton after passage through an atomic power station cooling circuits, Journal of Thermal Biology, 23, 91-97

Sashikumar, N. (1991). Ecology and control of biofouling in a coastal power station with special reference to Megabalanus tintinabulum (L), Ph. D. Thesis, University of Madras Madras, India

Sashikumar, N.; Nair, K. V. K. \& Azariah, J. (1990). Colonization of marine foulants at a power plant site, Proceedings of Indian Academy of Sciences, 99, 525-531

Sashikumar, N.; Rajagopal, S. \& Nair, K. V. K. (1989). Seasonal and vertical distribution of macrofoulants in Kalpakkam coastal waters, Indian Journal of Marine Sciences, $18,270-275$

Satpathy, K. K. \& Nair, K. V. K. (1990). Impact of power plant discharge on the physicochemical characteristics of Kalpakkam coastal waters, Mahasagar - Bulletin of National Institute of Oceanography, 23, 117-125 
Satpathy, K. K. (1990). Biofouling control measures in power plants- a brief over view. Proceedings of specialists meeting on marine biodeterioration with special reference to power plant cooling systems, pp. 153-166, WSCL, Kalpakkam, Tamil Nadu, India

Satpathy, K. K. (1996). Seasonal distribution of nutrients in the coastal waters of Kalpakkam, East Coast of India, Indian Journal of Marine Sciences, 25, 221-224

Satpathy, K. K. (1996). Studies on the chemical feature of cooling water systems in the context of scaling, biofouling and corrosion control, Ph.D. Thesis, University of Madras, Madras, India

Satpathy, K. K. (1999). Effect of biofouling on the cooling water quality of a nuclear power plant, Bulletin of Electrochemistry, 15, 143-147

Satpathy, K. K.; Jebakumar, K. E. \& Bhaskar, S. (2008). A novel technique for the measurement of temperature in outflow water from a coastal power plant with notes on chlorination and phytoplankton determinations, Journal of Thermal Biology, 33, 209-212

Satpathy, K. K.; Mohanty, A. K.; Prasad, M. V. R.; Bhaskar, S.; Jebakumar, K. E. \& Natesan, U. (2006). Impact of biofouling community on the cooling water quality with special emphasis on its nutrient content, Proceedings of the International Conference on Recent Advances in Marine Antifouling Technology, pp. 326-337, NIOT, Chennai, India

Satpathy, K. K.; Mohanty, A. K.; Prasad, M. V. R.; Natesan, U. \& Sarkar, S. K. (2010). Seasonal variation in physicochemical properties of coastal waters of kalpakkam, east coast of India with special emphasis on nutrients, Environmental Monitoring and Assessment, 164, 153-171

Satpathy, K. K.; Mohanty, A. K.; Prasad, M. V. R.; Natesan, U.; Sarkar, S. K. \& Rajan, M. (2008). Post-Tsunami changes in water quality of Kalpakkam coastal waters, east coast of India with special references to nutrients, Asian Journal of Water Environment and Pollution, 5, 15-30

Satpathy, K. K.; Nair, K. V. K. \& Mathur, P. K. (1992). Some observations on the water quality characteristics of coastal seawater and sub-seabed tunnel, Mahasagar Bulletin of National Institute of Oceanography, 25, 73-82

Satpathy, K. K.; Nair, K. V. K. \& Mathur, P. K. (1994). Chlorine demand \& chemical control of biofouling in power plant cooling system, In: Recent developments in biofouling control, M. P. Thompson \& R. Nagabhushanam, (Eds.), 397-407, Oxford \& IBH Publishing Company, New Delhi

Satpathy, K. K.; Venugopalan, V. P. \& Nair, K.V.K. (1999). Barnacle fouling control technology in power plant cooling system, In: Barnacle fouling ecophysiology $\mathcal{E}$ control technology, M. P. Thompson \& R. Nagbhushanam, (Eds.), 359-379, American Institute of Biological Sciences, Washington D.C.

Satpathy, K.K., Jebakumar, K.E. \& Kannan, S.E. (2003). Experience of Bio-fouling Problem and its control in the seawater cooled power plants in India. Seminar on condenser cooling water system of PFBR, Kalpakkam. p1-20.

Satpathy, K.K., Nair, K.V.K. \& Mathur, P.K. (1997). Distribution of nutrients in Kalpakkam coastal waters. In: Advances in Environmental Sciences (Ed. C.S.P. Iyer, Educational book publishers New Delhi), p181-186.

Sebastian, V. O. \& Kurian, C. V. (1981). Indian Ascidians, Oxford \& IBH Publishing Company, New Delhi, India 
Seed, R. (1969). The ecology of Mytilus edulis (lamellibranchiata) on exposed rocky shores. 1. Breeding and settlement, Oecologia, 3, 227-316

Sellers, M. A. \& Stanley, J. G. (1984). Species Profiles: Life histories and environmental requirements of coastal fishes and invertebrates (North Atlantic) American Oyster, TR EL-82-4, 15, U. S. Fish and Wildlife Service, U.S. Army Corps of Engineers

Shannon, C. E. \& Weaver, W. (1963). The mathematical theory of communication, University of Illinois Press, Urbana

Somayajulu, Y. K.; Ramana Murthy, T. V.; Prasanna Kumar, S. \& Sastry, J. S. (1987). Hydrographic characteristics of central Bay of Bengal waters during southwest monsoon of 1983, Indian Journal of Marine Sciences, 16, 207-217

Stone, A.B., Spyridakis, D.E., Benjamin, M.M., Ferguson, J.F., Reiber, S. and Osterhus, S. (1987). The effect of short term changes in water quality, on copper and zinc corrosion rates, Journal of American Water Works Association, February, 75-82

Strauss, S. D. (1989). New methods, chemicals improve control of biofouling, Power, January, 51-52

Suryanarayan, A. \& Rao, D. P. (1992). Coastal circulation and upwelling index along the east coast of India, Physical Processes in the Indian Seas (Proceedings of First Convention, ISPSO), pp. 125-129

Sutherland, J. P. (1981). The fouling community at Beufort, North Carolina: a study in stability, Nature, 118, 499-519

Swami, B. S. \& Chhapgar, B. F. (2002). Settlement pattern of ascidians in harbour waters of Mumbai, west coast of India, Indian Journal of Marine Sciences, 31, 207-212

Syrett, B. C. and Coit, R. L. (1983). Causes and prevention of power plant condenser tube failure, Material Performance, February, 44-50

Tennessse Valley Authority. (1981). Letter from L.M. Mills to J.P. O'reilly transmitting TVA'S response to the NRC IE Bulletin 81-03 for the Brown's Ferry Nuclear Plants

Varkey, M. J.; Murthy, V. S. N. \& Suryanarayan, A. (1996). Physical oceanography of the Bay of Bengal and Andaman Sea, In: Oceangraphy and Marine Biology, An Annual Review, A. D. Ansell; R. N. Gibson and M. Barnes, (Eds.), UCL Press, 34, 1-70

Venkateswarlu, K. S. (1990). Marine biofouling and its chemical control in power industry, Chemical Business, 20, 39-41

Venugopalan, V. P. \& Nair, K. V. K. (1990). Effect of biofouling community on cooling water characteristics of a coastal power plant, Indian Journal of Marine Sciences, 19, 294-296

Venugopalan, V. P. (1987). Studies on biofouling in the offshore waters of Arabian Sea. Ph. D. Thesis, University of Bombay, Bombay, India

Venugopalan, V. P.; Rajagopal, S.; Sashikumar, N. \& Nair, K. V. K. (1991). Marine biology of a seawater tunnel on the east coast of India, In: Oceanography of the Indian Ocean, B. N. Desai, (Ed.), 253-259

Vinaychandran, P. N.; Masumoto, Y.; Mikawa, T. \& Yamagata, T. (1999). Intrusion of the southwest monsoon current into the Bay of Bengal, Journal of Geophysical Research, 104, 11077-11085

White, G. C. (1972). Handbook of chlorination, Van Nostrand Reinhold Company, New York 
Whitehouse, J. W. (1975). Chlorination of cooling water: a review of literature on the effects of chlorine on aquatic organisms, CEGB Report no. SD/L/M/M 496, $1-22$

Whitehouse, J. W.; Khalanski, M; Sargolia, M. G. \& Jenner, H. A. (1985). The control of biofouling in marine \& estuarine power stations. A collaborative report by CEGB, EDF, ENEL \& KEMA. NW/R 19

Wyrtki, K. (1973). Physical oceanography of the Indian Ocean, In: Biology of the Indian Ocean, B. Zeitzshel, (Ed.), Springer Verlag Berlin, New York 


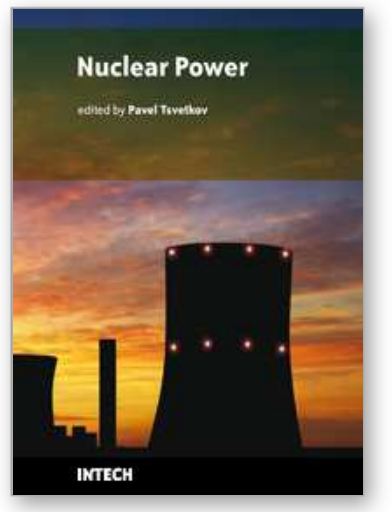

\author{
Nuclear Power \\ Edited by Pavel Tsvetkov
}

ISBN 978-953-307-110-7

Hard cover, 388 pages

Publisher Sciyo

Published online 17, August, 2010

Published in print edition August, 2010

The world of the twenty first century is an energy consuming society. Due to increasing population and living standards, each year the world requires more energy and new efficient systems for delivering it. Furthermore, the new systems must be inherently safe and environmentally benign. These realities of today's world are among the reasons that lead to serious interest in deploying nuclear power as a sustainable energy source. Today's nuclear reactors are safe and highly efficient energy systems that offer electricity and a multitude of co-generation energy products ranging from potable water to heat for industrial applications. The goal of the book is to show the current state-of-the-art in the covered technical areas as well as to demonstrate how general engineering principles and methods can be applied to nuclear power systems.

\title{
How to reference
}

In order to correctly reference this scholarly work, feel free to copy and paste the following:

Kamala Kanta Satpathy, Ajit Kumar Mohanty, Gouri Sahu, Sudipta Biswas and Selvanayagam M. (2010). Biofouling and its Control in Seawater Cooled Power Plant Cooling Water System - A Review, Nuclear Power, Pavel Tsvetkov (Ed.), ISBN: 978-953-307-110-7, InTech, Available from:

http://www.intechopen.com/books/nuclear-power/biofouling-and-its-control-in-seawater-cooled-power-plantcooling-water-system-a-review-

\section{INTECH}

open science | open minds

\author{
InTech Europe \\ University Campus STeP Ri \\ Slavka Krautzeka 83/A \\ 51000 Rijeka, Croatia \\ Phone: +385 (51) 770447 \\ Fax: +385 (51) 686166 \\ www.intechopen.com
}

\author{
InTech China \\ Unit 405, Office Block, Hotel Equatorial Shanghai \\ No.65, Yan An Road (West), Shanghai, 200040, China \\ 中国上海市延安西路65号上海国际贵都大饭店办公楼 405 单元 \\ Phone: +86-21-62489820 \\ Fax: +86-21-62489821
}


(C) 2010 The Author(s). Licensee IntechOpen. This chapter is distributed under the terms of the Creative Commons Attribution-NonCommercialShareAlike-3.0 License, which permits use, distribution and reproduction for non-commercial purposes, provided the original is properly cited and derivative works building on this content are distributed under the same license. 